\title{
Off the Waterfront: The long-run impact of technological change on dock workers*
}

\author{
Zouheir El-Sahli \\ Aix-Marseille University ${ }^{\dagger}$ \\ Richard Upward \\ University of Nottingham \\ Accepted by British Journal of Industrial Relations 3 January 2017
}

\begin{abstract}
We investigate how individual workers and local labour markets adjust over a long time period to a discrete and plausibly exogenous technological shock, namely the introduction of containerisation in the UK port industry. This technology, which was introduced rapidly between the mid-1960s and the late-1970s, had dramatic consequences for specific occupations within the port industry. Using longitudinal micro-census data we follow dock-workers over a 40 year period and examine the long-run consequences of containerisation for patterns of employment, migration and mortality. The results show that the job guarantees negotiated by the unions protected dock-workers' employment until the guarantees were removed in 1989. A matched comparison of workers in comparable unskilled occupations reveals that, even after job guarantees were removed, dock-workers did not fare worse than the comparison group in terms of their labour market outcomes. Our results suggest that job guarantees provided a safety net which reduced the cost to workers of sudden technological change.
\end{abstract}

Word count: 8747

\footnotetext{
${ }^{*}$ The permission of the Office for National Statistics to use the Longitudinal Study is gratefully acknowledged, as is the help provided by staff of the Centre for Longitudinal Study Information \& User Support (CeLSIUS). CeLSIUS is supported by the ESRC Census of Population Programme (award ref ES/K000365/1). The authors alone are responsible for the interpretation of the data. This work contains statistical data from ONS which is Crown Copyright. The use of the ONS statistical data in this work does not imply the endorsement of the ONS in relation to the interpretation or analysis of the statistical data. This work uses research datasets which may not exactly reproduce National Statistics aggregates.

†Corresponding author: Aix-Marseille Universite', GREQAM - Centre de la vieille Charit - 2 rue de la Charit - 13002 Marseille - France. Email: zouheir.EL-SAHLI@univ-amu.fr
} 


\section{Introduction}

Technological change can have dramatic and long-lasting effects on the labour market. Some industries, occupations or locations decline, while others expand as a result. This restructuring causes job loss and the displacement of workers from the declining industries or occupations, with consequent losses of employment and earnings for those who are displaced. Studies of displaced workers' earnings confirm that these losses are considerable. For the UK, to which this paper refers, Upward and Wright (2015) find long-run losses (10 years after displacement) in wages and employment which amount to a permanent reduction in earnings of about $10 \% .^{1}$ As well as the financial cost, there are also long-lasting effects on other worker outcomes, such as morbidity (e.g. Black et al., 2012), mortality (e.g. Eliason and Storrie, 2009) and family break-up (e.g. Eliason, 2012).

Until recently, the literature on job loss did not consider the underlying cause of the displacement. It is therefore difficult to evaluate the adjustment cost of specific technological developments which may simultaneously affect many firms, an entire industry or occupation. This is because such technological changes often occur relatively gradually, or because they are difficult to isolate from other changes which are occurring at the same time, or because the shocks may be themselves determined by the structure of the labour market. A recent exception is the work of Autor and co-authors (for example Autor, Dorn, Hanson and Song, 2014), which considers the effect of increased imports from China on workers' patterns of earnings and employment. Autor et al. show that workers whose industries were subsequently exposed to increased import competition from China experienced large and long-run losses in earnings, as well as greater rates of job loss. They argue that labour market rigidities prevent workers moving to new labour markets, industries or occupations, and this rigidity prevents the cost of the trade shock from being disbursed across workers more generally. This paper follows a similar approach. We consider a group of workers who were exposed to a sudden, well-defined and arguably exogenous technological shock, namely the introduction of containerisation to UK ports. We follow those workers over a long period of time (effectively their entire working lives) and examine their patterns of employment, unemployment and other labour market outcomes relative to a matched control group.

Containerisation changed the UK port industry profoundly in the space of only a few years, starting in the late 1960s. Figure 1 shows the percentage of all containerisable UK trade that was transported in containers from 1966 onwards. $^{2}$ Within just 10 years of the appearance of this new technology, $80 \%$ of all relevant UK trade was being moved in containers. ${ }^{3}$ The new technology was massively more capital intensive, and its introduction led to a sudden decline in the use of port labour, in particular those workers who loaded and unloaded cargo, known as stevedores, dockers or longshoremen. Containerisation also brought increased economies of scale and a greater concentration of port activity (Hall, 2009). Older ports which were unsuited to the requirements of the 
new technology (such as deep water, road and rail networks) declined while new ports expanded quickly in more suitable locations. London was one of the largest ports in the world before the advent of the container, and suffered a particularly dramatic decline. The port districts in East London lost some 150,000 jobs between 1966 and 1976 due to the closure of the London Docks, around $20 \%$ of all jobs in the area. ${ }^{4}$

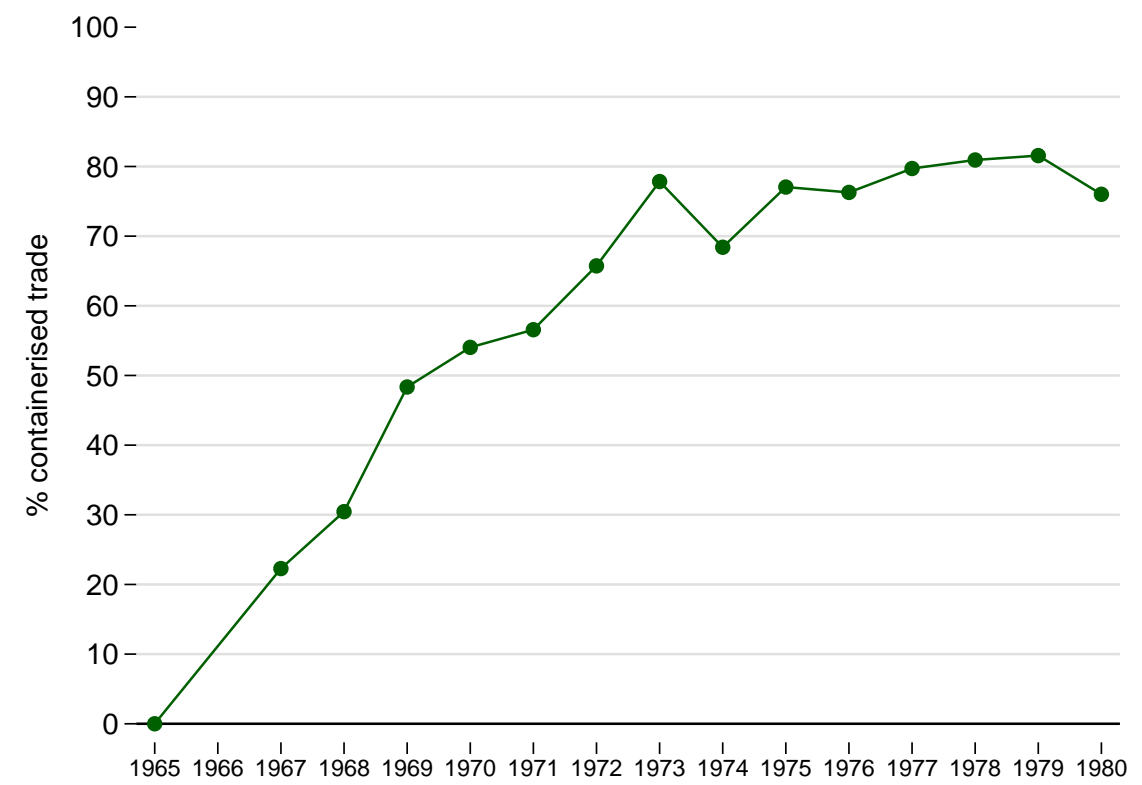

Figure 1. Containerisation penetration in UK trade measured as total UK containerisable trade by tonnage moved in containers as a percentage of total containerisable trade. Adapted from Bernhofen et al. (2016).

Beyond the effect on the port industry itself, containerisation also affected other industries which were traditionally located near ports. Hoare (1986) claims that, in 1964, $40 \%$ of all UK exports originated within 25 miles of their port of export, and twothirds within 75 miles. ${ }^{5}$ Containerisation and the associated development of rail and road networks meant that warehouses and manufacturers no longer needed to locate near ports.

Our approach in this paper is to measure the cost of the technological shock to incumbent workers. We use district-level and individual-level census data to follow dock workers (and various comparison groups) in England and Wales over a 40-year period from 1971 to 2011 to measure the long-run effect. We also consider the likely spillover effect on local labour markets, rather than just those workers directly affected. Our study bears some similarity to, and uses the same data as Fieldhouse and Hollywood (1999), who study the effects of the collapse of the UK mining industry during the 1980s. ${ }^{6}$ They find that only one-third of men in mining occupations in 1981 were in employment in 1991. In contrast, half of men in the same age group who were not in mining occupations in 1981 were in employment in 1991. Their results suggest that an industry-level collapse in employment can have extremely large employment effects even 
after 10 years. $^{7}$

As well as allowing us to follow workers over a very long time period, the census data also has the advantage that it tracks workers regardless of their labour market state. Typically, administrative data which come from social security records (such as that used by Jacobson et al., 1993) only contain records for those periods when the worker is in employment. But an important development in the UK (and US) labour markets over the last 30 years has been the large increase in the number claiming various disability benefits (see McVicar, 2008, for a survey of the UK evidence). In the US, Black et al. (2002) show that exogenous variation in the value of labour force participation has a significant effect on the use of disability programmes. Our data allows us to see the extent to which the new technology caused existing workers to enter different labour market states such as unemployment, disability or retirement. ${ }^{8}$

Our paper is also related to the literature on the effects of deregulation and containerisation on dock-workers in the United States. Talley (2002) analyzes the earnings of US union dock-workers before and after the passage of the 1984 Shipping Act, using CPS data. The results show that dock-worker earnings increased after deregulation, which is attributed to the increase in demand for dock-workers in the period after containerisation $^{9}$ and increased capital-labour ratios. Similarly, Hall (2009) estimates the effects of containerisation and deregulation on port worker earnings in US port cities since 1975. He also uses CPS data and constructs difference-in-difference estimates of earnings gaps between truckers, dockers and warehousers and various control groups based on workers in non-transport occupations based in port and non-port cities. He finds that dockers' pay advantage over non-transport workers also increased during the period of containerisation and deregulation. In contrast to these papers, we use longitudinal data which allows us to assess the impact of containerisation and deregulation on existing dock workers, rather than a comparison of cross-sections over time.

The paper is organized as follows. In Section 2 we briefly describe the process by which UK ports became containerized as well as the evolution of dock employment in the UK. Section 3 describes the location of English and Welsh ports and provides a district-level comparison of labour markets defined according to the location of ports. Our methods are described in Section 4, and the main set of worker-level results is provided in Section 5. Section 6 concludes.

\section{Dock Employment in Great Britain}

The development of container technology is described in detail in, for example, Vigarié (1999), Levinson (2006) and El-Sahli (2012). In this section we describe the most important developments as they affected the UK, with a particular focus on the effects of containerisation on port labour and employment in port areas. 
Container ships first docked in the UK in 1966, when services were established for the transatlantic trade between the US and European ports in the UK, Netherlands and West Germany (Levinson, 2006). Containerisation required major technological changes in port facilities, and the two largest UK ports of London and Liverpool were unsuitable for the new technology. London docks, for example, were difficult to navigate even for smaller break-bulk ships, ${ }^{10}$ and larger vessels had to unload onto smaller vessels near the mouth of the river. Furthermore, neither London nor Liverpool allowed easy access for onward land transportation. As a result, major investments were made in new docks at Tilbury and Southampton, while Liverpool docks were retro-fitted to handle containers in the early 1970s.

Before containerisation, dock-work was highly paid. The average full-time docker earned about 30\% more than the average male worker in Britain in the mid-1960s (Levinson, 2006). ${ }^{11}$ Dock-workers had high levels of unionisation and industrial disputes were common before the introduction of containers (Turnbull, 2012). In the UK, dock-work was highly regulated by the statutory National Dock Labour Scheme (NDLS). The NDLS was first signed in 1947 between employers and the Transport \& General Workers Union (TGWU) after years of very costly industrial disputes. Turnbull et al. (1996) claim that the root of all socio-economic ills on the waterfront was underemployment. The NDLS came to minimize that through the registration of dockworkers to control labor supply, centralized hiring, better labor mobility and industry-wide training. In addition, dockers were paid a daily attendance fee when they reported to work even if they are not given any tasks on the day. Also, a guaranteed weekly wage was instituted if earnings plus any attendance money fell below a nationally agreed minimum. In return for the guaranteed income and employment scheme, dockers were required to attend work on a daily basis and accept whatever work was given to them. ${ }^{12}$

With intensifying industrial action and the threat of technical change, a new dock scheme was signed in 1967. The new NDLS introduced permanent employment arrangements ${ }^{13}$ and prevented non-registered dockers from working in ports covered by the scheme (Turnbull et al., 1996). Voluntary severance was also offered with generous severance pay. Non-scheme ports flourished on the back of the new NDLS such as Felixstowe. Mechanization proved to be a significant factor in accounting for the marked increase in industrial disputes after 1967. The introduction of containers caused further industrial conflict: unions imposed a ban on container ships at Tilbury docks in January 1968, which lasted until April 1970. The dispute resulted in the negotiation of a new scheme, although there were continuing industrial disputes throughout the period of containerisation.

In 1972, another agreement was reached which prevented the use of compulsory redundancy. Even if the port employer went out of business, the worker would be offered dock-work with another employer if he was unwilling to accept voluntary severance (Turnbull and Wass, 1994). This agreement remained in place and the dock workers kept 


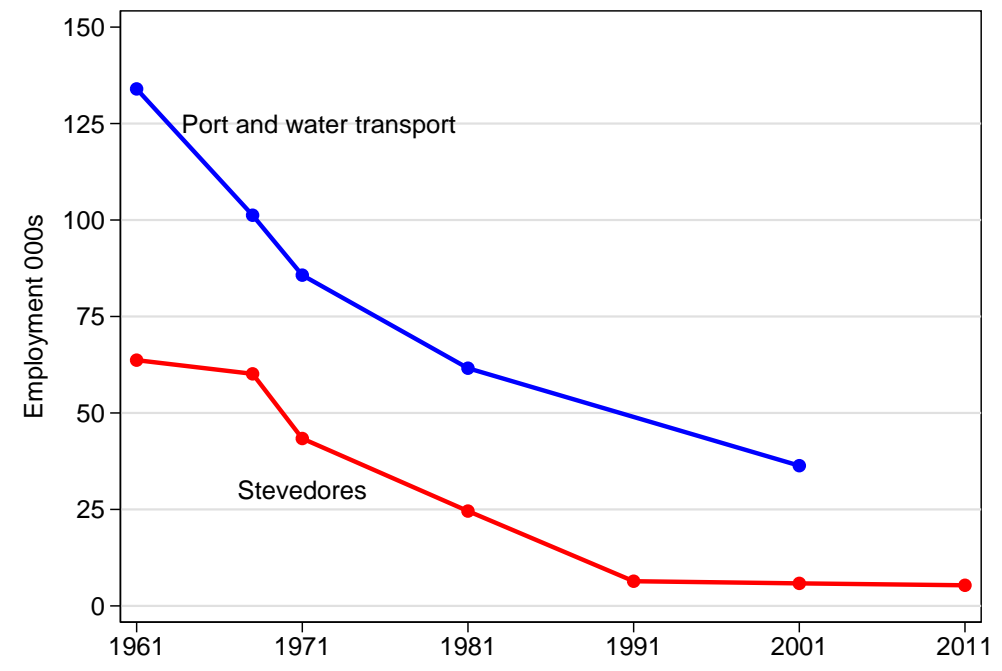

Figure 2. Employment (000s) in port industries and stevedore occupations 1961-2011 in Great Britain. Source: produced by authors based on published census $10 \%$ tables (1961, 1971 and 2001), New Earnings Survey (1981, 1991) and Digest of Port Statistics (1968). Industry employment for 1961-1981 is employment in "Port and inland water transport" whereas 2001 is employment in "Water transport" and is therefore not directly comparable. Industry figures are for England and Wales only. Occupation employment is employment as "Stevedore and dock labourer" in Great Britain. Figure for 1967 stevedores does not include stevedores hired by ports not covered by the Dock Labour Scheme. The number employed in ports in 1968 does not include inland waterways.

their job and wage guarantees until the NDLS was finally abolished by the government of Margaret Thatcher in July 1989. This led to large-scale dismissals in a short period of time. At some ports the entire registered dock labour force was dismissed, and over 7,200 dockers were declared redundant between 1989 and 1992 (Turnbull, 1992; Turnbull and Wass, 1994).

During this period of industrial disputes, an alternative port at Felixstowe was developed (essentially by installing new equipment) which, within a few years, became the largest UK container port. London docks (with the exception of Tilbury) closed from 1967 onwards, with the final closures occurring in $1983 .{ }^{14}$

Figure 2 plots the number of dock-workers and the total number of people employed in the port industry between 1961 and 2011. The number of dockers declined slightly from 1961, but fell more quickly as containerisation took hold from the late 1960s onwards. The total number employed in the Port and inland water transport industry also fell dramatically. Between 1961 and 2001 the industry lost over $72 \%$ of its employment, while the occupation of "dock-worker" lost over 90\%. The effective disappearance of dock-workers accounted for $60 \%$ of the total fall in employment in the industry. 


\section{District-level evidence}

In this section we provide evidence that the process of containerisation had long-lasting effects at the level of the local labour market. We do this by comparing the labour market performance of districts which contained a major port in the 1960s with those that did not. An advantage of this approach is that we can use published census data which includes 1961 (clearly before containerisation), whereas the worker-level data we use in Section 5 is restricted to the period from 1971 onwards.

Figure 3 illustrates the location of the major ports which were in operation in England and Wales in 1967, largely before the process of containerisation began in the UK. ${ }^{15}$ Also shown are the local authority boundaries which existed at this time in England and Wales. ${ }^{16}$ Figure 3 shows clearly the importance of the traditional ports of London and Liverpool before containerisation, and also that port activity was quite widely spread at this time. We use the location of these ports shown in Figure 3 to define each local authority as "port" or "non-port". ${ }^{17}$

In Figure 4 we plot the employment and unemployment rates of port local authorities against non-port local authorities over the period 1961-2011. Panel (a) shows that in 1961 and 1971 the employment rate in port local authorities was slightly higher than in non-port local authorities, but experienced a steeper decline between 1971 and 1981 and did not start to recover until the 1991-2001 period. The employment gap between the two groups of districts is significantly wider even in 2011 than it was in 1961. Panel (b) shows a similar pattern for the unemployment rate, with a steeper increase in unemployment in port districts between 1971-1991, although in this case the port districts already had worse performance in 1961 and 1971. It is important to note that in neither panel (a) or (b) is there evidence of divergent labour market performance of port districts before 1971, despite the rapid introduction of containers shown in Figure 1.

Panel (c) of Figure 4 shows the precipitous decline in manufacturing employment that has occurred in the UK over the last fifty years. This decline has been even greater for local authorities which contained major ports in 1961, although it is striking that manufacturing employment in port districts actually increased somewhat between 1961 and 1971. Finally, panel (d) confirms that employment in transport-related industries was nearly twice as high in port local authorities in 1961 (and also increased between 1961 and 1971), but then declined. The timing of these changes is consistent with the idea that the introduction of containers reduced employment both in ports but also in the associated manufacturing industries, albeit with a short lag.

This graphical evidence from local labour markets can be summarised by a district- 


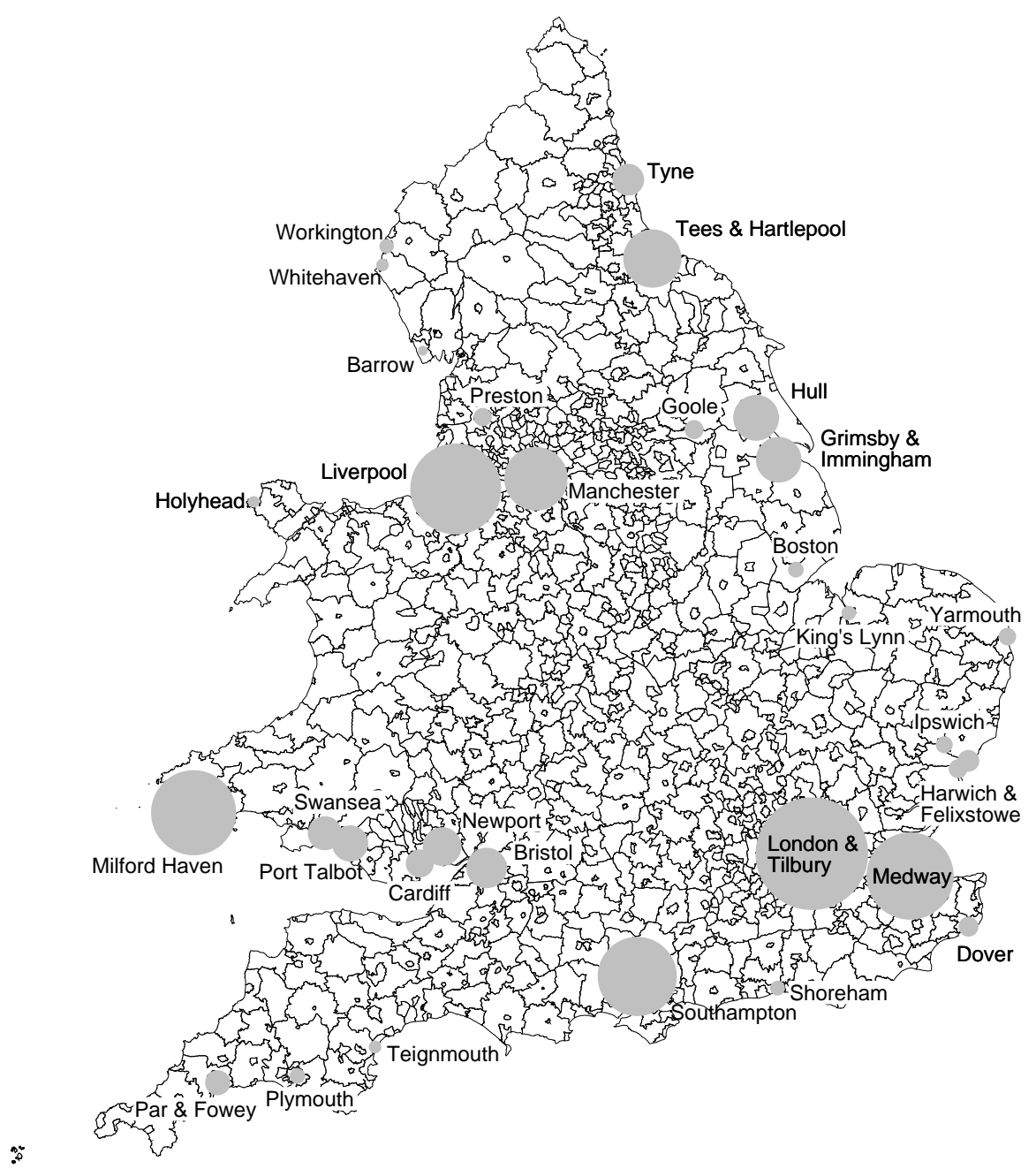

Figure 3. Location of the largest English and Welsh ports (measured by foreign tonnage) in 1967 (Digest of Port Statistics 1968). See Table A1 in Appendix A for a list of major ports. The size of each circle is proportional to that port's foreign tonnage in 1967. 
(a) Employment rate

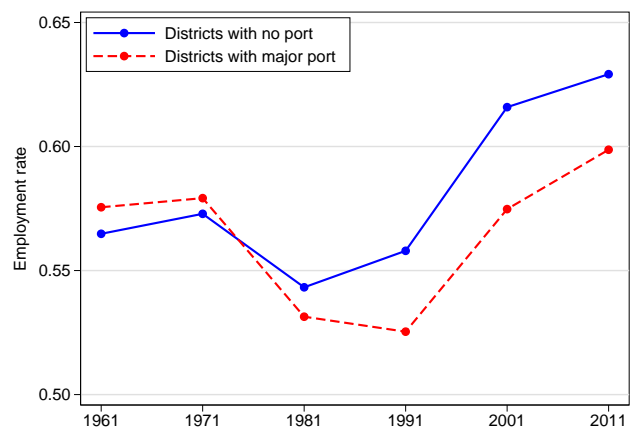

(c) Manufacturing employment

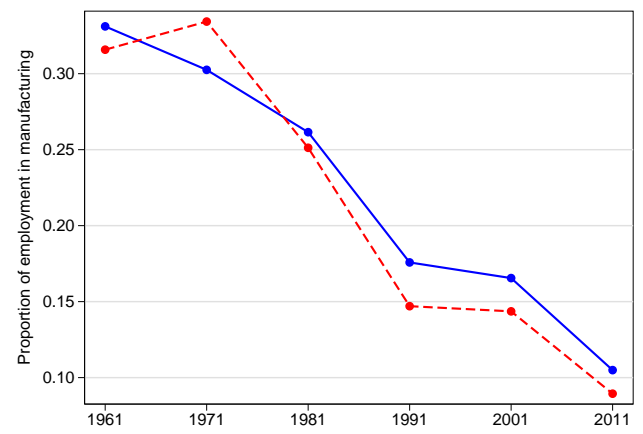

(b) Unemployment rate

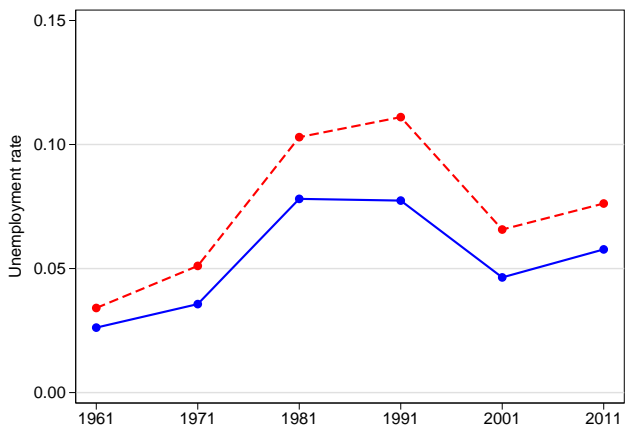

(d) Transport employment

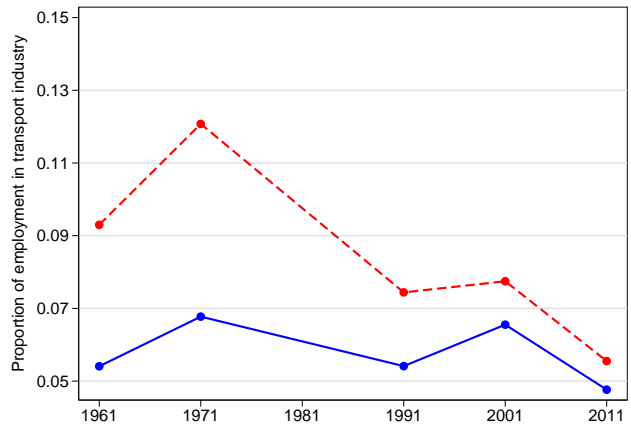

Figure 4. Employment rates of port and non-port districts 1961-2011. Panel (a) shows proportion of population aged $16+$ in employment. Panel (b) shows proportion of economically active in unemployment. Panel (c) shows proportion of employment in manufacturing industries. Panel (d) shows proportion of employment in transport industries. Source: UK Census data. Districts containing major ports are identified in Table A2 in Appendix A. The definition of "districts" changes considerably over time (section 3). "Transport industries" are not consistently defined in the 1981 census tables and this year is excluded from panel (d). 
level difference-in-difference model:

$$
y_{d t}=\alpha+\beta D_{d}+\sum_{s=1971}^{2011} \gamma^{s} T_{t}^{s}+\sum_{s=1971}^{2011} \delta^{s}\left(T_{t}^{s} \times D_{d}\right)+\epsilon_{d t},
$$

where the dependent variable is the relevant rate (employment, unemployment etc) in district $d$ at time $t$. The year indicator $T_{t}^{s}$ takes the value 1 if $t=s$. The treatment indicator $D_{d}$ takes the value 1 if $d$ is a district containing a major port and 0 otherwise. The treatment group will in this case be quite broad, and will include many workers who were not directly employed by docks. However, as we argued in the introduction, the containerisation of the docks had profound effects not only on dock-workers, but also on workers whose firms were located close to docks or whose firms provided services related to shipping.

The results are shown in Table 1, where each column (a)-(d) shows the estimate corresponding to panels (a)-(d) in Figure 4. The estimate of $\beta$ shows that the employment rate and the proportion of employment in manufacturing in 1961 was not significantly different in port districts relative to non-port districts. However, the unemployment rate was nearly one percentage point higher and the proportion of employment in transport industries was nearly 4 percentage points higher. The estimates of $\delta$ then show how these rates evolved over the following 50 years. Employment rates in port districts decline relative to those in non-port districts from 1981 onwards and are still significantly lower (4.1pp) even in 2011. However, the unemployment effect seems to have been somewhat smaller, and there is also some evidence of a divergent trend between 1961 and 1971. The fact that the negative employment effect is larger than the positive unemployment effect reflects the fact that those workers who lost their jobs as a result of containerisation could not remain unemployed indefinitely, but will have retired or left the labour force.

In the third column we see that the DiD assumption of common trends is clearly violated, since port districts had stronger growth rates of manufacturing employment between 1961 and 1971; this was no longer the case from 1971 onwards. The fourth column confirms that transport employment declined much more strongly in port districts.

The district-level results from this section suggest that labour markets which contained a major port in the 1960s fared worse than labour markets which did not contain a major port, and that this difference has persisted for many years. Furthermore, the results suggests that this difference emerged, with a short lag, after the introduction of containerisation in UK ports. This is at least suggestive of the idea that (a) the effects of containerisation were felt more generally than simply within the docks and (b) these effects were very long-lasting.

However, this evidence does not control for characteristics of the workers or industries in each district which are time-varying. ${ }^{18}$ It seems plausible, for example, that districts 


\begin{tabular}{lcccc}
\hline & $\begin{array}{c}\text { Emp. } \\
\text { rate (a) }\end{array}$ & $\begin{array}{c}\text { Unemp. } \\
\text { rate (b) }\end{array}$ & $\begin{array}{c}\text { Manuf. } \\
\text { rate (c) }\end{array}$ & $\begin{array}{c}\text { Trans. } \\
\text { rate (d) }\end{array}$ \\
\hline$\beta$ & 0.011 & $0.008^{* * *}$ & -0.015 & $0.039^{* * *}$ \\
& $(0.007)$ & $(0.002)$ & $(0.019)$ & $(0.006)$ \\
$\delta^{1971}$ & -0.004 & $0.007^{* * *}$ & $0.047^{* * *}$ & $0.014^{*}$ \\
& $(0.004)$ & $(0.001)$ & $(0.015)$ & $(0.008)$ \\
$\delta^{1981}$ & $-0.023^{* * *}$ & $0.017^{* * *}$ & 0.005 & \\
& $(0.006)$ & $(0.004)$ & $(0.016)$ & \\
$\delta^{1991}$ & $-0.043^{* * *}$ & $0.026^{* * *}$ & -0.013 & $-0.019^{* * *}$ \\
& $(0.008)$ & $(0.004)$ & $(0.017)$ & $(0.007)$ \\
$\delta^{2001}$ & $-0.052^{* * *}$ & $0.011^{* * *}$ & -0.007 & $-0.027^{* * *}$ \\
& $(0.010)$ & $(0.003)$ & $(0.018)$ & $(0.007)$ \\
$\delta^{2011}$ & $-0.041^{* * *}$ & $0.011^{* * *}$ & -0.000 & $-0.031^{* * *}$ \\
& $(0.009)$ & $(0.003)$ & $(0.019)$ & $(0.006)$ \\
Number of obs. & 8,196 & 8,196 & 8,196 & 6,830 \\
Number of districts & 1,366 & 1,366 & 1,366 & 1,366 \\
Number of parameters & 11 & 11 & 11 & 9 \\
$R^{2}$ & 0.290 & 0.493 & 0.375 & 0.175 \\
\hline
\end{tabular}

Table 1. District level difference-in-difference estimates (1961-2011). Table reports estimates of Equation (1). "Transport industries" are not consistently defined in the 1981 census tables and this year is excluded from the final column.

which contained ports had different occupational and industrial structures and that these districts might have fared worse than other districts regardless of the introduction of containerisation. In addition, the district-level evidence does not tell us directly about adjustment costs. If, for example, workers move from declining districts (such as those containing ports) to expanding districts, then adjustment costs may be low even though there are large differences in employment growth between districts. In the next section therefore we turn to individual level data which allow us to track incumbent workers, and which allow us to control for the pre-existing characteristics of workers, including occupation and industry.

\section{Data and Research Design}

Individual micro-level data for England and Wales is taken from the Office for National Statistics Longitudinal Study (LS). ${ }^{19}$ The sample comprises individuals born on one of four selected dates during the year, and therefore represents slightly more than $1 \%$ of the population of England and Wales. Records are linked across each 10-year census from 1971 to 2011. A disadvantage of our data is therefore that we first observe workers a few years after the process of containerisation started. Nevertheless, Figure 2 suggests that about two-thirds of stevedores remained by 1971, and the evidence from Section 3 shows that the "shock" in terms of overall employment did not occur until after 1971. The LS includes information from the census on occupation, economic activity, housing, 
ethnicity, age, sex, marital status and education. Additional information on events such as death and migration is also available. The LS does not contain information on earnings, however. Figure 5 shows the geographic distribution of workers in the LS who report working in port-related industries. ${ }^{20}$ It is reassuring to note that the concentrations of these workers correspond very closely to the locations of ports shown in Figure 3.

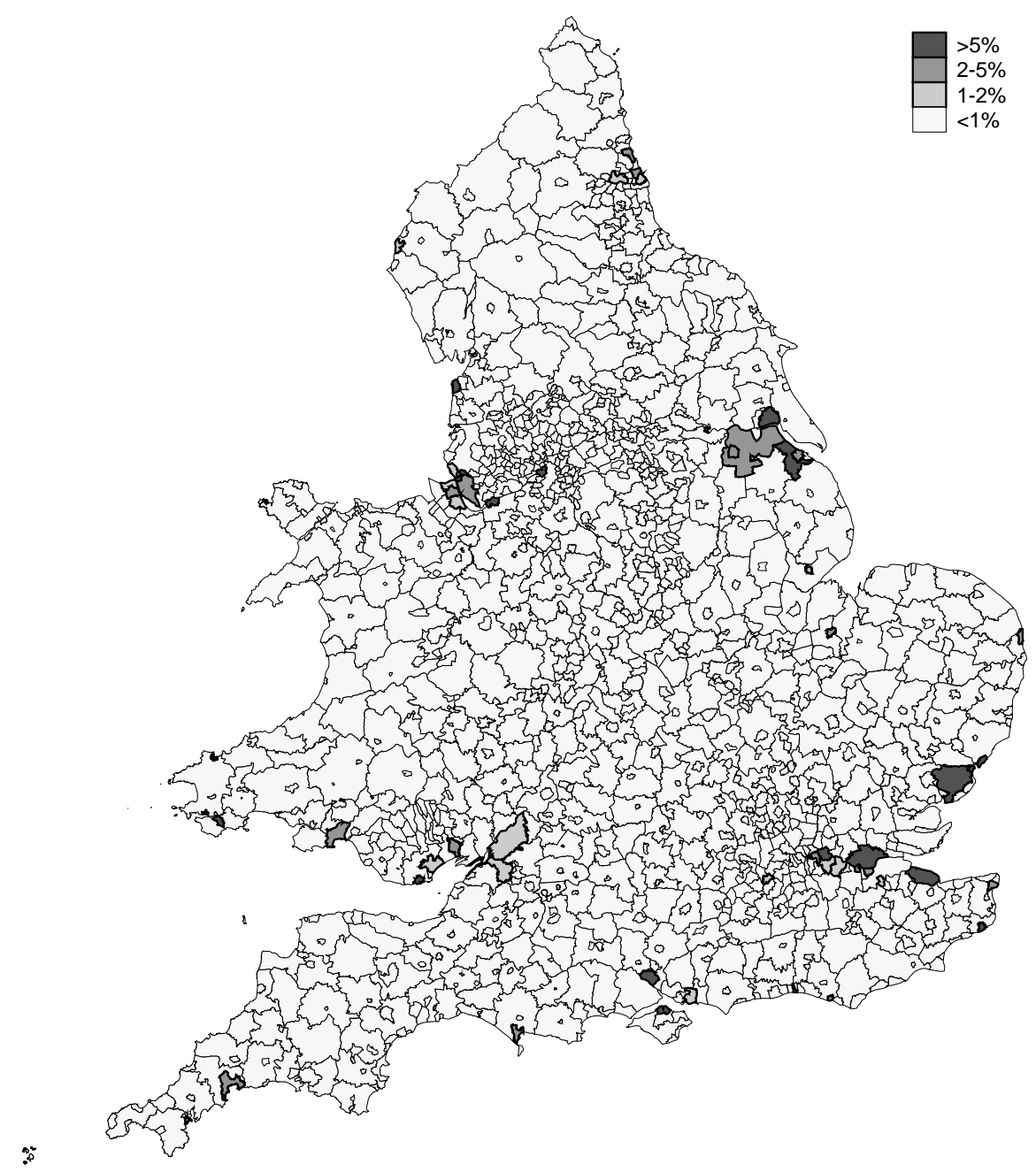

Figure 5. Employment in port-related industries in each Local Authority district in 1971 (Authors' calculations from the 1971 Longitudinal Study). The classification of Local Authorities which contained ports is given in Table A2 in Appendix A.

The data allows us to follow a sample of employed men in 1971 and trace patterns of employment or re-employment (in new occupations, industries and places of work), unemployment or inactivity. Because we can do this over a long time period we can capture, for most workers, their entire working lives after the introduction of the new technology. We focus on groups of workers who were likely to have been affected by the introduction of containers. These groups include dock-workers, workers in port industries and workers who work close to docks. We compare these groups to observationally similar 


\begin{tabular}{llrrrrr}
\hline & & 1971 & 1981 & 1991 & 2001 & 2011 \\
\hline & $\begin{array}{l}\text { Original sample, excluding self-employed } \\
\text { and those above 65 in 1971 }\end{array}$ & 124,335 & 102,860 & 86,585 & 66,876 & 49,450 \\
& & & & & & \\
$D 1=1$ & Stevedores & 397 & 344 & 272 & 191 & 123 \\
$D 1=0$ & Non-stevedores in manual occupations, & 51,706 & 42,707 & 35,709 & 27,356 & 20,206 \\
& excluding transport sector & & & & & \\
$D 2=1$ & Non-stevedores in port industry & 424 & 352 & 272 & 202 & 131 \\
$D 2=0$ & Workers not in the transport industry & 112,895 & 93,343 & 78,628 & 60,948 & 45,255 \\
& & & & & & \\
$D 3=1$ & Workers in districts with a major port & 19,752 & 16,270 & 13,701 & 10,594 & 7,898 \\
$D 3=0$ & Workers in districts with no major port & 93,143 & 77,073 & 64,927 & 50,354 & 37,357 \\
& & & & & & \\
\hline
\end{tabular}

Table 2. Definition of control and treatment groups. All definitions apply to the sample only in 1971; changes in sample sizes in subsequent years are therefore entirely due to attrition. The sample includes only men because all of the workers identified as stevedores in 1971 were men. All the D3 comparisons exclude workers in the transport sector. All treatment groups are mutually exclusive, so for example $D 3$ excludes those with $D 1=1$ or $D 2=1$.

workers who are less directly affected by the process of containerisation.

Our complete sample comprises 201,091 individuals who were employed at the time of the census in April 1971 as employees, apprentices, foremen and managers. ${ }^{21}$ From these we select only men, since all the individuals identified as stevedores in 1971 were men. This leaves us with 124,335 male workers observed in 1971. The first row of Table 2 shows that $83 \%$ of these workers are also observed 10 years later in the 1981 census. About half of those who are not observed in subsequent censuses have died; the remainder could not be traced or linked. The attrition rate increases over each 10year interval because the sample ages and therefore the proportion dying increases. The remaining rows of Table 2 summarise our main treatment and control groups.

The first treatment group $D 1$ is defined by occupation. The UK classification of occupations in use at the time of the 1971 census (Office for Population Censuses and Surveys, 1970) has a specific category for "Stevedores and dock labourers". We find 397 individuals in this occupational group, which is consistent with the estimated number of stevedores from the published census tables (Figure 2 shows that there were about 43,000 Stevedores in Great Britain in 1971). Rather than using all workers who are not stevedores as a control group, we restrict the control group to include only those workers in social classes 3 ("skilled manual") and 5 ("unskilled"), since all stevedores fall into these classes. We also restrict the control group to exclude workers in transport industries to avoid the potential problem that containerisation had effects on other industries in the transport sector.

The second treatment group D2 is defined by industry. The UK classification of industries at the time of the 1971 census (Central Statistical Office, 1970) has a classification for 'Port and inland water transport'. We find 759 men in this industry, which 
again is consistent with the estimates from published census tables shown in Figure 2. To make the different treatment groups mutually exclusive, we remove stevedores from treatment group $D 2$ and keep only workers in the port industry that are not stevedores. The $D 2$ control group includes all workers not in transport industries.

The third treatment group $D 3$ is defined by geography. Using the districts defined in Section 3 (i.e. those that contained major ports in 1971), a worker is in treatment group D3 if their place of work falls in one of those districts in 1971, and is in the control group otherwise. We remove individuals that belong to treatment groups $D 1$ and $D 2$ to ensure that all three treatment groups are mutually exclusive, and we also exclude workers in the transport industry. By doing this we capture any spillovers from containerisation which occurred in non-transport industries as a result of their location.

Once we have defined the treatment and control groups, we require information on those same workers in each of the following censuses up to 2011. We create a panel with five observations for each individual $(t=1971,1981,1991,2001,2011)$. Define $y_{i t}$ to be the outcome of individual $i$ at time $t$. These outcomes will be indicator variables capturing employment status, occupational mobility, geographic mobility and mortality. Define $D_{i}$ to be an indicator variable which takes the value 1 if individual $i$ is in the treatment group in 1971 and 0 otherwise. Define $T_{i t}^{81}$ to be an indicator variable which takes the value 1 if observation $i$ refers to year 1981 . $T_{i t}^{91}, T_{i t}^{01}$ and $T_{i t}^{11}$ are defined analogously.

We measure the effect of containerisation by comparing the evolution of $y_{i t}$ between individuals in the treatment group and those in the control group. In each case the base year (1971) is such that everyone in the sample has $y_{i t}=1$ because everyone in the sample is in employment (and in the census) in that year, or because their mobility status is undefined. Therefore we estimate a simplified difference model (rather than a difference-in-difference model as before):

$$
y_{i t}=\alpha+\sum_{s=1991}^{2011} \gamma^{s} T_{t}^{s}+\sum_{s=1981}^{2011} \delta^{s}\left(T_{t}^{s} \times D_{i}\right)+\epsilon_{i t} .
$$

The coefficients $\gamma^{s}$ capture the evolution of $y_{i t}$ over the next three decades for individuals in the control group, while the $\delta^{s}$ coefficients capture the difference in the evolution of $y_{i t}$ for the treatment group.

We also need to consider pre-existing observed differences between the treatment and control groups in 1971. For example, the treatment and control group may differ in terms of age, education, occupation and so on. To illustrate the differences between the treatment and control groups in terms of their characteristics, Table 3 compares the mean values for each treatment/control comparison.

For definitions $D 1$ and $D 2$, the treatment group is significantly older, more likely 


\begin{tabular}{|c|c|c|c|c|c|c|c|c|c|}
\hline & \multicolumn{3}{|c|}{$\begin{array}{c}D 1 \\
\text { (stevedores vs. } \\
\text { other occupations) }\end{array}$} & \multicolumn{3}{|c|}{$\begin{array}{c}D 2 \\
\text { (port industry vs. } \\
\text { other industries) }\end{array}$} & \multicolumn{3}{|c|}{$\begin{array}{l}\qquad D 3 \\
\text { (port district vs. } \\
\text { other districts) }\end{array}$} \\
\hline & $D 1=1$ & $D 1=0$ & $p$-value & $D 2=1$ & $D 2=0$ & $p$-value & $D 3=1$ & $D 3=0$ & $p$-value \\
\hline Age & 42.89 & 38.84 & {$[0.000]$} & 44.19 & 39.10 & {$[0.000]$} & 39.14 & 39.09 & {$[0.626]$} \\
\hline Marital status ( $1=$ single $)$ & 0.10 & 0.24 & {$[0.000]$} & 0.15 & 0.24 & {$[0.000]$} & 0.24 & 0.23 & {$[0.219]$} \\
\hline Higher degree & 0.00 & 0.00 & {$[0.831]$} & 0.00 & 0.01 & {$[0.347]$} & 0.01 & 0.01 & {$[0.001]$} \\
\hline Other Degree & 0.00 & 0.00 & {$[0.635]$} & 0.03 & 0.05 & {$[0.029]$} & 0.05 & 0.05 & {$[0.003]$} \\
\hline Other qualif. above A-level & 0.00 & 0.01 & {$[0.145]$} & 0.02 & 0.04 & {$[0.006]$} & 0.05 & 0.04 & {$[0.422]$} \\
\hline A-level & 0.01 & 0.03 & {$[0.011]$} & 0.04 & 0.07 & {$[0.029]$} & 0.07 & 0.06 & {$[0.003]$} \\
\hline Below A-level & 0.99 & 0.96 & {$[0.006]$} & 0.92 & 0.83 & {$[0.000]$} & 0.82 & 0.84 & {$[0.000]$} \\
\hline Primary industry & 0.00 & 0.06 & - & 0.00 & 0.05 & {$[0.000]$} & 0.01 & 0.06 & {$[0.000]$} \\
\hline Manufacturing & 0.00 & 0.58 & - & 0.00 & 0.48 & - & 0.47 & 0.49 & {$[0.000]$} \\
\hline Construction & 0.00 & 0.14 & - & 0.00 & 0.09 & - & 0.10 & 0.09 & {$[0.000]$} \\
\hline Energy & 0.00 & 0.03 & - & 0.00 & 0.03 & - & 0.03 & 0.02 & {$[0.000]$} \\
\hline Transport & 1.00 & 0.00 & - & 1.00 & 0.00 & - & 0.00 & 0.00 & - \\
\hline Services & 0.00 & 0.19 & - & 0.00 & 0.35 & - & 0.39 & 0.34 & {$[0.000]$} \\
\hline Professional & 0.00 & 0.00 & - & 0.02 & 0.05 & {$[0.006]$} & 0.06 & 0.05 & {$[0.000]$} \\
\hline Intermediate & 0.00 & 0.00 & - & 0.14 & 0.17 & {$[0.110]$} & 0.18 & 0.16 & {$[0.000]$} \\
\hline Skilled non-manual & 0.00 & 0.00 & - & 0.21 & 0.12 & {$[0.000]$} & 0.15 & 0.11 & {$[0.000]$} \\
\hline Skilled manual & 0.23 & 0.84 & {$[0.000]$} & 0.31 & 0.38 & {$[0.001]$} & 0.36 & 0.39 & {$[0.000]$} \\
\hline Partly skilled & 0.00 & 0.00 & - & 0.25 & 0.18 & {$[0.001]$} & 0.16 & 0.19 & {$[0.000]$} \\
\hline Unskilled manual & 0.77 & 0.16 & {$[0.000]$} & 0.07 & 0.07 & {$[0.692]$} & 0.08 & 0.07 & {$[0.000]$} \\
\hline Other occupation & 0.00 & 0.00 & - & 0.00 & 0.02 & {$[0.012]$} & 0.01 & 0.02 & {$[0.000]$} \\
\hline North & 0.05 & 0.08 & {$[0.016]$} & 0.04 & 0.07 & {$[0.046]$} & 0.09 & 0.06 & {$[0.000]$} \\
\hline Yorkshire and Humberside & 0.11 & 0.12 & {$[0.846]$} & 0.08 & 0.10 & {$[0.158]$} & 0.05 & 0.11 & {$[0.000]$} \\
\hline North West & 0.20 & 0.14 & {$[0.001]$} & 0.27 & 0.14 & {$[0.000]$} & 0.28 & 0.11 & {$[0.000]$} \\
\hline East Midlands & 0.01 & 0.08 & {$[0.000]$} & 0.01 & 0.07 & {$[0.000]$} & 0.00 & 0.09 & {$[0.000]$} \\
\hline West Midlands & 0.00 & 0.13 & {$[0.000]$} & 0.00 & 0.12 & {$[0.000]$} & 0.00 & 0.14 & {$[0.000]$} \\
\hline East Anglia & 0.02 & 0.03 & {$[0.136]$} & 0.02 & 0.03 & {$[0.321]$} & 0.03 & 0.03 & {$[0.172]$} \\
\hline South East & 0.49 & 0.29 & {$[0.000]$} & 0.40 & 0.35 & {$[0.017]$} & 0.36 & 0.35 & {$[0.000]$} \\
\hline South West & 0.06 & 0.06 & {$[0.487]$} & 0.07 & 0.07 & {$[0.814]$} & 0.09 & 0.07 & {$[0.000]$} \\
\hline Wales & 0.07 & 0.06 & {$[0.466]$} & 0.09 & 0.05 & {$[0.000]$} & 0.09 & 0.04 & {$[0.000]$} \\
\hline Male unemployment rate (ward) & 6.10 & 4.19 & {$[0.000]$} & 5.13 & 3.89 & {$[0.000]$} & 4.78 & 3.70 & {$[0.000]$} \\
\hline$\%$ unskilled workers (ward) & 14.49 & 8.32 & {$[0.000]$} & 10.43 & 7.45 & {$[0.000]$} & 9.33 & 7.05 & {$[0.000]$} \\
\hline \% semi-skilled workers (ward) & 19.59 & 17.53 & {$[0.000]$} & 17.57 & 16.73 & {$[0.015]$} & 16.80 & 16.72 & {$[0.136]$} \\
\hline Number of observations & 397 & 51,706 & & 424 & 112,895 & & 19,752 & 93,143 & \\
\hline
\end{tabular}

Table 3. Pre-existing differences in sample characteristics in 1971. The $D 1$ treatment and control groups include only manual workers. The $D 1$ and $D 2$ treatment groups include only those in the port industry (and therefore in the transport sector). All three control groups exclude workers in the transport sector.

to be married and more likely to have educational qualifications below A-level. ${ }^{22}$ For definition D3 (based on geography), the pre-existing differences in personal characteristics are much smaller. $77 \%$ of the $D 1$ treatment group are classified as being in social class 5 ("unskilled") and $23 \%$ in social class 3 ("skilled manual"). We restrict the $D 1$ control group to the same social classes, but note that their distribution across those two classes is completely different. $69 \%$ of the $D 1$ treatment group have their workplace in the South East and the North West (see Figure 3). For all three classification D1, $D 2$ and D3, the local labour market unemployment rate and the proportion of unskilled employment in 1971 are significantly higher for the treatment groups than the control groups.

To control for these pre-existing differences, we explicitly match treatment observations with observationally similar control observations using the propensity score method proposed by Rosenbaum and Rubin (1983). ${ }^{23}$ The propensity score $p(\mathbf{x})$ is defined as the probability of being in the treatment group given a set of pre-existing observable 


\begin{tabular}{|c|c|c|c|c|c|c|c|c|c|}
\hline & \multicolumn{3}{|c|}{$\begin{array}{c}D 1 \\
\text { (stevedores vs. } \\
\text { other occupations) }\end{array}$} & \multicolumn{3}{|c|}{$\begin{array}{l}\qquad D 2 \\
\text { (port industry vs. } \\
\text { other industries) }\end{array}$} & \multicolumn{3}{|c|}{$\begin{array}{l}\qquad D 3 \\
\text { (port district vs. } \\
\text { other districts) }\end{array}$} \\
\hline & $D 1=1$ & $D 1=0$ & $p$-value & $D 2=1$ & $D 2=0$ & $p$-value & $D 3=1$ & $D 3=0$ & $p$-value \\
\hline Age & 43.02 & 43.01 & {$[0.974]$} & 44.31 & 44.19 & {$[0.459]$} & 39.19 & 39.23 & {$[0.702]$} \\
\hline Marital status ( $1=$ single $)$ & 0.09 & 0.09 & {$[0.275]$} & 0.15 & 0.15 & {$[0.896]$} & 0.23 & 0.23 & {$[0.039]$} \\
\hline Higher degree & 0.00 & 0.00 & - & 0.00 & 0.00 & {$[0.798]$} & 0.01 & 0.01 & {$[0.973]$} \\
\hline Other Degree & 0.00 & 0.00 & - & 0.03 & 0.03 & {$[0.578]$} & 0.05 & 0.06 & {$[0.108]$} \\
\hline Other qualif. above A-level & 0.00 & 0.00 & - & 0.02 & 0.02 & {$[0.742]$} & 0.05 & 0.05 & {$[0.099]$} \\
\hline A-level & 0.01 & 0.01 & {$[0.599]$} & 0.04 & 0.04 & {$[0.283]$} & 0.07 & 0.07 & {$[0.346]$} \\
\hline Below A-level & 0.99 & 0.99 & {$[0.599]$} & 0.91 & 0.91 & {$[0.239]$} & 0.82 & 0.82 & {$[0.012]$} \\
\hline Primary industry & & & & & & & 0.01 & 0.01 & {$[0.627]$} \\
\hline Manufacturing & & & & & & & 0.47 & 0.47 & {$[0.272]$} \\
\hline Construction & & & & & & & 0.10 & 0.09 & {$[0.368]$} \\
\hline Energy & & & & & & & 0.03 & 0.03 & {$[0.107]$} \\
\hline Transport & & & & & & & 0.00 & 0.00 & - \\
\hline Services & & & & & & & 0.39 & 0.40 & {$[0.329]$} \\
\hline Professional & 0.00 & 0.00 & - & 0.02 & 0.02 & {$[0.883]$} & 0.06 & 0.06 & {$[0.134]$} \\
\hline Intermediate & 0.00 & 0.00 & - & 0.13 & 0.13 & {$[0.100]$} & 0.18 & 0.18 & {$[0.018]$} \\
\hline Skilled non-manual & 0.00 & 0.00 & - & 0.22 & 0.22 & {$[0.844]$} & 0.15 & 0.16 & {$[0.017]$} \\
\hline Skilled manual & 0.25 & 0.25 & {$[1.000]$} & 0.31 & 0.31 & {$[0.907]$} & 0.36 & 0.35 & {$[0.005]$} \\
\hline Partly skilled & 0.00 & 0.00 & - & 0.25 & 0.25 & {$[0.896]$} & 0.16 & 0.16 & {$[0.197]$} \\
\hline Unskilled & 0.75 & 0.75 & {$[1.000]$} & 0.07 & 0.07 & {$[0.102]$} & 0.08 & 0.08 & {$[0.676]$} \\
\hline Other Occupation & 0.00 & 0.00 & - & 0.00 & 0.00 & {$[0.470]$} & 0.01 & 0.01 & {$[0.047]$} \\
\hline North & 0.05 & 0.05 & {$[0.863]$} & 0.04 & 0.04 & {$[0.846]$} & 0.09 & 0.10 & {$[0.000]$} \\
\hline Yorkshire and Humberside & 0.11 & 0.12 & {$[0.514]$} & 0.08 & 0.08 & {$[0.382]$} & 0.05 & 0.04 & {$[0.000]$} \\
\hline North West & 0.18 & 0.19 & {$[0.078]$} & 0.27 & 0.27 & {$[0.409]$} & 0.28 & 0.27 & {$[0.078]$} \\
\hline East Midlands & 0.01 & 0.01 & {$[0.863]$} & 0.01 & 0.01 & {$[0.173]$} & 0.00 & 0.00 & {$[0.896]$} \\
\hline West Midlands & 0.00 & 0.00 & {$[0.054]$} & 0.00 & 0.01 & {$[0.000]$} & 0.00 & 0.00 & {$[0.001]$} \\
\hline East Anglia & 0.02 & 0.02 & {$[0.787]$} & 0.02 & 0.02 & {$[0.782]$} & 0.03 & 0.03 & {$[0.524]$} \\
\hline South East & 0.49 & 0.48 & {$[0.263]$} & 0.40 & 0.39 & {$[0.053]$} & 0.36 & 0.36 & {$[0.387]$} \\
\hline South West & 0.06 & 0.06 & {$[0.466]$} & 0.08 & 0.07 & {$[0.575]$} & 0.09 & 0.10 & {$[0.000]$} \\
\hline Wales & 0.07 & 0.07 & {$[0.454]$} & 0.09 & 0.10 & {$[0.187]$} & 0.09 & 0.09 & {$[0.566]$} \\
\hline Male unemployment rate (ward) & 5.72 & 5.89 & {$[0.010]$} & 5.04 & 5.16 & {$[0.005]$} & 4.71 & 4.62 & {$[0.000]$} \\
\hline$\%$ of unskilled workers (ward) & 13.47 & 13.42 & {$[0.706]$} & 10.27 & 10.47 & {$[0.013]$} & 9.20 & 9.07 & {$[0.001]$} \\
\hline$\%$ of semi-skilled workers (ward) & 19.45 & 19.77 & {$[0.002]$} & 17.62 & 17.69 & {$[0.387]$} & 16.75 & 16.54 & {$[0.000]$} \\
\hline Number of observations & 361 & 11,886 & & 409 & 28,269 & & 19,031 & 75,627 & \\
\hline
\end{tabular}

Table 4. Pre-existing differences in sample characteristics in 1971, after propensity score matching. Sample $D 1$ are matched within occupations. Industry is not used for matching samples $D 1$ and $D 2$ because the treatment group consists only of those working in the transport sector and the control group excludes the transport sector.

characteristics, $\mathbf{x}$ :

$$
p(\mathbf{x})=\operatorname{Pr}\left\{D_{i}=1 \mid \mathbf{x}_{i}\right\} .
$$

The scores are estimated from a Logit model. The matching method has the advantage, compared to linear regression, that it imposes a common support on the treated and untreated observations. That is, we only include in the control group those observations whose characteristics are such that they have a propensity score similar to some observations in the treatment group. In practice, this means we compare dock-workers, those who work in port industries, or those who work in port districts to workers who were observably similar in 1971. Because we typically have a very large control group we choose the 100 nearest matches to each treated observation but restrict matches to be within 0.001 of the propensity for treated observations.

In Table 4 we report the means of the treatment and control groups after matching. In contrast to Table 3, the observable characteristics of the treated and control sam- 
ples are almost all insignificantly different from each other. For sample $D 1$ we match within occupation, which is why the sample is perfectly balanced across skilled manual (25\%) and unskilled (75\%). Note that for $D 1$ we do not match on industry because the treatment group consists entirely of workers in the transport sector, while the control group excludes the transport sector. Similarly for sample $D 2$ we do not match on sector because the treatment and control groups are defined by sector. Almost all the treatment observations in Table 3 are also in the matched samples shown in Table 4, which shows that almost all treated observations have one or more observations from the control group with similar characteristics. Thus, the effect of matching is to select from the full control group a subset of observations which are more similar to the treatment group. For example, the matched control group $D 1=0$ comprises 11, 886 observations drawn from the original control group of 51, 706 .

After matching, the effect of containerisation is estimated as the average treatment effect on the treated. This is estimated as the mean difference in the outcome for each matched stevedore with the outcome for an appropriately-weighted group of matched non-stevedores, see Eqn (25.40) in Cameron and Trivedi (2005):

$$
A T E T=\frac{1}{N^{T}} \sum_{i \in D=1}\left[y_{1, i}-\sum_{j} w(i, j) y_{0, j}\right]
$$

In this expression $N^{T}$ is the number of stevedores, $y_{1, i}$ is the outcome for the $i=1 \ldots N^{T}$ stevedores and $y_{0, j}$ is the outcome for the set of matched non-stevedores. Each matched non-stevedore has a weight $w(i, j)$ determined by the matching estimator. In practice, the ATET can be estimated from Equation (2) on the matched treatment and control groups where the observations in the control group are weighted by $w(i, j)$.

\section{Results}

In this section, we present the results from estimating Equation (2) using the treatment and control group definitions given in Table 2. We estimate a number of models to examine the extent to which the treatment group experienced differential rates of: (1) attrition and mortality, (2) labour market states, (3) geographic and occupational mobility.

\subsection{Attrition and mortality}

We start by considering the extent to which the treatment and control groups differ in terms of their appearance in the LS. As shown in Table 2, the proportion of individuals who can be linked across 10-year intervals declines from $83 \%$ in $1971-1981$ to $74 \%$ in 2001-2011. Model (1) "In census" therefore examines whether the treatment group 
are more likely to exit the sample. Of the exits from the sample, around half are not linked because of death of the respondent. The LS records year of death, from which we create an indicator variable which takes the value 1 if the respondent has died before the following census date. Model (2) "Died" therefore examines whether the treatment group are more likely to die. ${ }^{24}$ Estimates of Models (1) "In census" and (2) "Died" are shown in Table 5. We estimate each model using treatment and control groups $D 1$, $D 2$ and D3 as defined in Table 2. The top panel shows the raw differences between the treatment and control groups, while the bottom panel shows the differences after matching on observable characteristics.

In panel (a) of Table 5 estimates of $\alpha$ and $\gamma$ are similar for samples D1, D2 and D3 because the (very large) control groups are roughly similar in all three samples. Estimates of $\alpha$ shows that $83 \%$ of the control group remain in the sample in 1981, while the estimates of $\gamma^{s}$ show that a further $13.5 \%$ of the control group leave the sample by $1991,29.7 \%$ by 2001 and so on. The estimates of $\delta$ for samples $D 1$ and $D 2$ show that the treatment group had higher attrition rates in 2001 and 2011. In other words, workers who were stevedores in 1971 or who worked in port industries in 1971 are less likely to be observed in the sample in 2001 and 2011. However, for sample D3 the differences between the treatment and control groups are much smaller and generally insignificantly different from zero. Estimates of Model (2) show that this difference in attrition rates between the treatment and control groups is entirely due to different death rates. For example, the $D 1$ treatment group are $8.1 \mathrm{pp}$ less likely to appear in the sample in 2011 than the control group $\left(\delta^{2011}=-0.081\right.$ with a standard error of 0.023$)$, and this is entirely explained by the fact that they are 9.8pp more likely to have died by 2011 $\left(\delta^{2011}=0.098\right.$ with a standard error of 0.025$)$.

The raw differences in attrition and mortality shown in panel (a) do not account for the significant differences in the characteristics of the treatment and control groups shown in Table 3. Most obviously, stevedores $(D 1=1)$ and those who work in port industries $(D 2=1)$ are older and less educated than the control groups. In panel (b) of Table 5 we therefore report estimates of Equation (2) after matching on characteristics in 1971. The process of matching fundamentally changes the composition of the control group. Comparing the sample sizes in Table 3 with Table 4, we can see that almost all of the $D 1$ treatment group are in the matched sample (361 out of 397), but these are matched to only a small fraction of the control group (11,886 out of 51,706$)$. The matched control group are more than four years older than the unmatched control group and they are also far more likely to be in unskilled occupations $(75 \%$ in the matched control group compared to $16 \%$ in the unmatched control group).

These changes to the composition of the control group have large effects on the outcomes shown in Table 5. Consider the attrition rate and mortality rate of the control group. In panel (a) column $1 \gamma^{2011}$ is estimated to be -0.435 ; this increases to -0.507 (in absolute value) in panel (b). Similarly, the mortality rate increases from 0.478 to 


\begin{tabular}{|c|c|c|c|c|c|c|}
\hline & \multicolumn{2}{|c|}{$\begin{array}{c}D 1 \\
\text { (stevedores vs. } \\
\text { other occupations) }\end{array}$} & \multicolumn{2}{|c|}{$\begin{array}{l}\qquad D 2 \\
\text { (port industry vs. } \\
\text { other industries) }\end{array}$} & \multicolumn{2}{|c|}{$\begin{array}{l}\text { D3 } \\
\text { (port district vs. } \\
\text { other districts) }\end{array}$} \\
\hline & $\begin{array}{l}\text { Model }(1) \\
\text { In census }\end{array}$ & $\begin{array}{l}\text { Model (2) } \\
\text { Died }\end{array}$ & $\begin{array}{l}\text { Model }(1) \\
\text { In census }\end{array}$ & $\begin{array}{l}\text { Model (2) } \\
\text { Died }\end{array}$ & $\begin{array}{l}\text { Model }(1) \\
\text { In census }\end{array}$ & $\begin{array}{l}\text { Model (2) } \\
\text { Died }\end{array}$ \\
\hline \multicolumn{7}{|c|}{ (a) Raw differences } \\
\hline$\alpha$ & $\begin{array}{l}0.826^{* * *} \\
(0.002)\end{array}$ & $\begin{array}{l}0.081^{* * *} \\
(0.001)\end{array}$ & $\begin{array}{l}0.827^{* * *} \\
(0.001)\end{array}$ & $\begin{array}{l}0.079^{* * *} \\
(0.001)\end{array}$ & $\begin{array}{l}0.827^{* * *} \\
(0.001)\end{array}$ & $\begin{array}{l}0.079^{* * *} \\
(0.001)\end{array}$ \\
\hline$\gamma^{1991}$ & $\begin{array}{c}-0.135^{* * *} \\
(0.002)\end{array}$ & $\begin{array}{l}0.143^{* * *} \\
(0.002)\end{array}$ & $\begin{array}{c}-0.130^{* * *} \\
(0.001)\end{array}$ & $\begin{array}{l}0.137^{* * *} \\
(0.001)\end{array}$ & $\begin{array}{c}-0.130^{* * *} \\
(0.001)\end{array}$ & $\begin{array}{l}0.137^{* * *} \\
(0.001)\end{array}$ \\
\hline$\gamma^{2001}$ & $\begin{array}{c}-0.297^{* * *} \\
(0.002)\end{array}$ & $\begin{array}{l}0.316^{* * *} \\
(0.002)\end{array}$ & $\begin{array}{c}-0.287^{* * *} \\
(0.002)\end{array}$ & $\begin{array}{l}0.306^{* * *} \\
(0.001)\end{array}$ & $\begin{array}{c}-0.287^{* * *} \\
(0.002)\end{array}$ & $\begin{array}{l}0.306^{* * *} \\
(0.002)\end{array}$ \\
\hline$\gamma^{2011}$ & $\begin{array}{c}-0.435^{* * *} \\
(0.002)\end{array}$ & $\begin{array}{l}0.478^{* * *} \\
(0.002)\end{array}$ & $\begin{array}{c}-0.426^{* * *} \\
(0.002)\end{array}$ & $\begin{array}{l}0.467^{* * *} \\
(0.002)\end{array}$ & $\begin{array}{c}-0.426^{* * *} \\
(0.002)\end{array}$ & $\begin{array}{l}0.467^{* * *} \\
(0.002)\end{array}$ \\
\hline$\delta^{1981}$ & $\begin{array}{c}0.041^{* *} \\
(0.017)\end{array}$ & $\begin{array}{c}-0.012 \\
(0.013)\end{array}$ & $\begin{array}{c}0.003 \\
(0.018)\end{array}$ & $\begin{array}{l}0.040^{* *} \\
(0.016)\end{array}$ & $\begin{array}{c}-0.004 \\
(0.003)\end{array}$ & $\begin{array}{c}0.001 \\
(0.002)\end{array}$ \\
\hline$\delta^{1991}$ & $\begin{array}{c}-0.005 \\
(0.023)\end{array}$ & $\begin{array}{c}0.020 \\
(0.022)\end{array}$ & $\begin{array}{c}-0.055^{* *} \\
(0.023)\end{array}$ & $\begin{array}{l}0.095^{* * *} \\
(0.023)\end{array}$ & $\begin{array}{c}-0.003 \\
(0.004)\end{array}$ & $\begin{array}{c}0.003 \\
(0.003)\end{array}$ \\
\hline$\delta^{2001}$ & $\begin{array}{r}-0.048^{*} \\
(0.025)\end{array}$ & $\begin{array}{l}0.051^{* *} \\
(0.026)\end{array}$ & $\begin{array}{c}-0.063^{* * *} \\
(0.024)\end{array}$ & $\begin{array}{l}0.104^{* * *} \\
(0.025)\end{array}$ & $\begin{array}{c}-0.004 \\
(0.004)\end{array}$ & $\begin{array}{c}0.003 \\
(0.004)\end{array}$ \\
\hline$\delta^{2011}$ & $\begin{array}{c}-0.081^{* * *} \\
(0.023)\end{array}$ & $\begin{array}{l}0.098^{* * *} \\
(0.025)\end{array}$ & $\begin{array}{c}-0.092^{* * *} \\
(0.022)\end{array}$ & $\begin{array}{l}0.121^{* * *} \\
(0.024)\end{array}$ & $\begin{array}{c}-0.001 \\
(0.004)\end{array}$ & $\begin{array}{c}0.002 \\
(0.004)\end{array}$ \\
\hline Number of obs. & 208,412 & 193,905 & 453,276 & 420,264 & 451,580 & 418,629 \\
\hline Number of ind. & 52,103 & 49,965 & 113,319 & 108,449 & 112,895 & 108,031 \\
\hline$R^{2}$ & 0.114 & 0.150 & 0.109 & 0.145 & 0.109 & 0.145 \\
\hline \multicolumn{7}{|c|}{ (b) Matched on 1971 characteristics } \\
\hline$\alpha$ & $\begin{array}{l}0.766^{* * *} \\
(0.008)\end{array}$ & $\begin{array}{l}0.099^{* * *} \\
(0.005)\end{array}$ & $\begin{array}{l}0.801^{* * *} \\
(0.003)\end{array}$ & $\begin{array}{l}0.111^{* * *} \\
(0.003)\end{array}$ & $\begin{array}{l}0.826^{* * *} \\
(0.002)\end{array}$ & $\begin{array}{l}0.079^{* * *} \\
(0.001)\end{array}$ \\
\hline$\gamma^{1991}$ & $\begin{array}{c}-0.160^{* * *} \\
(0.009)\end{array}$ & $\begin{array}{l}0.179^{* * *} \\
(0.008)\end{array}$ & $\begin{array}{c}-0.174^{* * *} \\
(0.004)\end{array}$ & $\begin{array}{l}0.187^{* * *} \\
(0.003)\end{array}$ & $\begin{array}{c}-0.129^{* * *} \\
(0.002)\end{array}$ & $\begin{array}{l}0.136^{* * *} \\
(0.002)\end{array}$ \\
\hline$\gamma^{2001}$ & $\begin{array}{c}-0.363^{* * *} \\
(0.011)\end{array}$ & $\begin{array}{l}0.412^{* * *} \\
(0.011)\end{array}$ & $\begin{array}{c}-0.368^{* * *} \\
(0.004)\end{array}$ & $\begin{array}{l}0.399^{* * *} \\
(0.004)\end{array}$ & $\begin{array}{c}-0.290^{* * *} \\
(0.003)\end{array}$ & $\begin{array}{l}0.310^{* * *} \\
(0.002)\end{array}$ \\
\hline$\gamma^{2011}$ & $\begin{array}{c}-0.507^{* * *} \\
(0.010)\end{array}$ & $\begin{array}{l}0.597^{* * *} \\
(0.010)\end{array}$ & $\begin{array}{c}-0.518^{* * *} \\
(0.004)\end{array}$ & $\begin{array}{l}0.575^{* * *} \\
(0.004)\end{array}$ & $\begin{array}{c}-0.432^{\text {*** }} \\
(0.003)\end{array}$ & $\begin{array}{l}0.474^{\text {*** }} \\
(0.003)\end{array}$ \\
\hline$\delta^{1981}$ & $\begin{array}{l}0.107^{* * *} \\
(0.019)\end{array}$ & $\begin{array}{r}-0.026^{*} \\
(0.015)\end{array}$ & $\begin{array}{c}0.030 \\
(0.019)\end{array}$ & $\begin{array}{c}0.010 \\
(0.016)\end{array}$ & $\begin{array}{c}0.001 \\
(0.003)\end{array}$ & $\begin{array}{c}0.001 \\
(0.002)\end{array}$ \\
\hline$\delta^{1991}$ & $\begin{array}{l}0.081^{* * *} \\
(0.026)\end{array}$ & $\begin{array}{r}-0.029 \\
(0.025)\end{array}$ & $\begin{array}{c}0.024 \\
(0.024)\end{array}$ & $\begin{array}{c}0.007 \\
(0.023)\end{array}$ & $\begin{array}{r}-0.000 \\
(0.004)\end{array}$ & $\begin{array}{c}0.003 \\
(0.004)\end{array}$ \\
\hline$\delta^{2001}$ & $\begin{array}{l}0.065^{* *} \\
(0.028)\end{array}$ & $\begin{array}{c}-0.045 \\
(0.029)\end{array}$ & $\begin{array}{c}0.051^{* *} \\
(0.025)\end{array}$ & $\begin{array}{c}-0.024 \\
(0.025)\end{array}$ & $\begin{array}{c}0.003 \\
(0.004)\end{array}$ & $\begin{array}{r}-0.002 \\
(0.004)\end{array}$ \\
\hline$\delta^{2011}$ & $\begin{array}{c}0.043^{*} \\
(0.025)\end{array}$ & $\begin{array}{c}-0.029 \\
(0.028)\end{array}$ & $\begin{array}{c}0.027 \\
(0.023)\end{array}$ & $\begin{array}{c}-0.019 \\
(0.024)\end{array}$ & $\begin{array}{c}0.008^{*} \\
(0.004)\end{array}$ & $\begin{array}{r}-0.006 \\
(0.005)\end{array}$ \\
\hline Number of obs. & 48,988 & 45,186 & 114,712 & 107,403 & 378,632 & 350,816 \\
\hline Number of ind. & 12,247 & 11,653 & 28,678 & 27,593 & 94,658 & 90,545 \\
\hline$R^{2}$ & 0.175 & 0.216 & 0.154 & 0.184 & 0.110 & 0.147 \\
\hline
\end{tabular}

Table 5. Differences in attrition rates and mortality between treated and control groups, 1981-2011. 
0.597. Similar increases are observed for sample $D 2$. Note that matching has much smaller effects for sample $D 3$ because the treatment and control groups are more similar before matching. The estimates of $\delta^{s}$ in panel (b) no longer indicate that the treatment group had worse outcomes. $\delta^{s}$ is now positive for Model (1) and negative for Model (2) for all $s=1981, \ldots, 2011$. Thus, once we restrict the control group to consist of men who are observably similar to stevedores, the treatment group do not have higher attrition rates or higher mortality rates. Indeed, if anything the treatment group have lower attrition rates, albeit the differences are only marginally significant by 2011. Also, interestingly, matched stevedores in Model (2) are less likely to die than the control group in 1981 with a $10 \%$ level of significance. Differences in attrition and mortality rates are smaller for sample $D 2$ and generally insignificant, showing that these differences are confined to the particular occupation of stevedores, rather than workers in port industries more generally. Differences in attrition and mortality rates are much smaller again for sample D3, and suggest little effect of containerisation on workers in port districts more generally.

\subsection{Employment status}

In Tables 6 and 7 we consider outcomes for different employment states. Recall that everyone in the sample is in employment in 1971. In each successive census, individuals report their labour market status at the time of the census. For men, four labour market states account for the vast majority of observations: employment (including selfemployment), unemployment, retirement, sickness/disability. Models (3)-(6) take each of these four states as the dependent variable. Precise definitions of each labour market state change slightly over the 1981-2011 censuses, and are summarised in Table B1 in Appendix B.

First consider the raw probabilities of each labour market state in 1981, shown in panel (a) of Tables 6 and 7. For sample D1, estimates of $\alpha$ show that, in 1981, 74\% of the control group are in employment, $8 \%$ are unemployed, $14 \%$ are retired and $3.7 \%$ are permanently sick or disabled. As the sample ages the proportion in employment falls and the proportion retired or sick increases, as indicated by the estimates of $\gamma^{s}$. We observe similar patterns for samples $D 2$ and $D 3$. There are large differences between the employment patterns of the treatment and control groups in panel (a). For sample $D 1$, stevedores are 17pp less likely to be in employment in 1991, 6.6pp more likely to be retired and $6.9 \mathrm{pp}$ more likely to be sick or disabled. A similar picture emerges for sample $D 2$, where port-industry workers are 15 pp less likely to be in employment and 9.3pp more likely to be retired. We also see smaller but still significant differences for sample $D 3$, where the treatment group (those living in port districts) are significantly less likely to be in employment and significantly more likely to be retired or sick in $1991 .^{25}$ 


\begin{tabular}{|c|c|c|c|c|c|c|}
\hline & \multicolumn{2}{|c|}{$\begin{array}{c}D 1 \\
\text { (stevedores vs. } \\
\text { other occupations) }\end{array}$} & \multicolumn{2}{|c|}{$\begin{array}{c}D 2 \\
\text { (port industry vs. } \\
\text { other industries) }\end{array}$} & \multicolumn{2}{|c|}{$\begin{array}{c}D 3 \\
\text { (port district vs. } \\
\text { other districts) }\end{array}$} \\
\hline & $\begin{array}{l}\text { Model (3) } \\
\text { Emp. }\end{array}$ & $\begin{array}{l}\text { Model (4) } \\
\text { Unemp. }\end{array}$ & $\begin{array}{l}\text { Model (3) } \\
\text { Emp. }\end{array}$ & $\begin{array}{c}\text { Model (4) } \\
\text { Unemp. }\end{array}$ & $\begin{array}{l}\text { Model (3) } \\
\text { Emp. }\end{array}$ & $\begin{array}{c}\text { Model (4) } \\
\text { Unemp. }\end{array}$ \\
\hline \multicolumn{7}{|c|}{ (a) Raw differences } \\
\hline$\alpha$ & $\begin{array}{l}0.741^{\text {*** }} \\
(0.002)\end{array}$ & $\begin{array}{l}0.078^{* * *} \\
(0.001)\end{array}$ & $\begin{array}{l}0.764^{* * *} \\
(0.001)\end{array}$ & $\begin{array}{l}0.061^{* * *} \\
(0.001)\end{array}$ & $\begin{array}{l}0.766^{* * *} \\
(0.002)\end{array}$ & $\begin{array}{l}0.060^{* * *} \\
(0.001)\end{array}$ \\
\hline$\gamma^{1991}$ & $\begin{array}{c}-0.162^{* * *} \\
(0.003)\end{array}$ & $\begin{array}{c}-0.018^{* * *} \\
(0.002)\end{array}$ & $\begin{array}{c}-0.173^{* * *} \\
(0.002)\end{array}$ & $\begin{array}{c}-0.011^{* * *} \\
(0.001)\end{array}$ & $\begin{array}{c}-0.172^{* * *} \\
(0.002)\end{array}$ & $\begin{array}{c}-0.011^{* * *} \\
(0.001)\end{array}$ \\
\hline$\gamma^{2001}$ & $\begin{array}{c}-0.282^{* * *} \\
(0.004)\end{array}$ & $\begin{array}{c}-0.057^{* * *} \\
(0.002)\end{array}$ & $\begin{array}{c}-0.313^{* * *} \\
(0.002)\end{array}$ & $\begin{array}{c}-0.042^{* * *} \\
(0.001)\end{array}$ & $\begin{array}{c}-0.310^{* * *} \\
(0.003)\end{array}$ & $\begin{array}{c}-0.042^{\text {*** }} \\
(0.001)\end{array}$ \\
\hline$\gamma^{2011}$ & $\begin{array}{c}-0.408^{* * *} \\
(0.004)\end{array}$ & $\begin{array}{c}-0.061^{* * *} \\
(0.002)\end{array}$ & $\begin{array}{c}-0.450^{* * *} \\
(0.003)\end{array}$ & $\begin{array}{c}-0.047^{* * *} \\
(0.001)\end{array}$ & $\begin{array}{c}-0.448^{* * *} \\
(0.003)\end{array}$ & $\begin{array}{c}-0.046^{* * *} \\
(0.001)\end{array}$ \\
\hline$\delta^{1981}$ & $\begin{array}{c}-0.009 \\
(0.024)\end{array}$ & $\begin{array}{c}-0.025^{* *} \\
(0.012)\end{array}$ & $\begin{array}{c}-0.076^{* * *} \\
(0.025)\end{array}$ & $\begin{array}{c}0.007 \\
(0.013)\end{array}$ & $\begin{array}{c}-0.012^{* * *} \\
(0.004)\end{array}$ & $\begin{array}{l}0.007^{* * *} \\
(0.002)\end{array}$ \\
\hline$\delta^{1991}$ & $\begin{array}{c}-0.174^{* * *} \\
(0.030)\end{array}$ & $\begin{array}{c}0.025 \\
(0.017)\end{array}$ & $\begin{array}{c}-0.150^{* * *} \\
(0.030)\end{array}$ & $\begin{array}{c}0.023 \\
(0.016)\end{array}$ & $\begin{array}{c}-0.013^{* * *} \\
(0.005)\end{array}$ & $\begin{array}{r}0.004^{*} \\
(0.002)\end{array}$ \\
\hline$\delta^{2001}$ & $\begin{array}{c}-0.145^{* * *} \\
(0.034)\end{array}$ & $\begin{array}{c}-0.015^{* * *} \\
(0.005)\end{array}$ & $\begin{array}{c}-0.168^{* * *} \\
(0.032)\end{array}$ & $\begin{array}{c}0.001 \\
(0.010)\end{array}$ & $\begin{array}{c}-0.029^{* * *} \\
(0.005)\end{array}$ & $\begin{array}{c}0.003^{*} \\
(0.002)\end{array}$ \\
\hline$\delta^{2011}$ & $\begin{array}{c}-0.178^{* * *} \\
(0.033)\end{array}$ & $\begin{array}{c}-0.000 \\
(0.011)\end{array}$ & $\begin{array}{c}-0.154^{* * *} \\
(0.032)\end{array}$ & $\begin{array}{c}-0.007 \\
(0.008)\end{array}$ & $\begin{array}{c}-0.020^{* * *} \\
(0.006)\end{array}$ & $\begin{array}{l}0.004^{* *} \\
(0.002)\end{array}$ \\
\hline Number of obs. & 126,863 & 126,852 & 279,009 & 278,988 & 278,052 & 278,031 \\
\hline Number of ind. & 44,964 & 44,964 & 98,018 & 98,018 & 97,657 & 97,657 \\
\hline$R^{2}$ & 0.089 & 0.014 & 0.109 & 0.010 & 0.108 & 0.010 \\
\hline \multicolumn{7}{|c|}{ (b) Matched on 1971 characteristics } \\
\hline$\alpha$ & $\begin{array}{l}0.666^{* * *} \\
(0.011)\end{array}$ & $\begin{array}{l}0.118^{* * *} \\
(0.008)\end{array}$ & $\begin{array}{l}0.685^{* * *} \\
(0.004)\end{array}$ & $\begin{array}{l}0.063^{* * *} \\
(0.002)\end{array}$ & $\begin{array}{l}0.762^{* * *} \\
(0.002)\end{array}$ & $\begin{array}{l}0.061^{\text {*** }} \\
(0.001)\end{array}$ \\
\hline$\gamma^{1991}$ & $\begin{array}{c}-0.255^{* * *} \\
(0.014)\end{array}$ & $\begin{array}{c}-0.019 \\
(0.012)\end{array}$ & $\begin{array}{c}-0.224^{* * *} \\
(0.005)\end{array}$ & $\begin{array}{c}-0.015^{* * *} \\
(0.003)\end{array}$ & $\begin{array}{c}-0.184^{* * *} \\
(0.003)\end{array}$ & $\begin{array}{c}-0.011^{* * *} \\
(0.002)\end{array}$ \\
\hline$\gamma^{2001}$ & $\begin{array}{c}-0.397^{* * *} \\
(0.015)\end{array}$ & $\begin{array}{c}-0.102^{* * *} \\
(0.009)\end{array}$ & $\begin{array}{c}-0.375^{* * *} \\
(0.006)\end{array}$ & $\begin{array}{c}-0.047^{* * *} \\
(0.002)\end{array}$ & $\begin{array}{c}-0.325^{* * *} \\
(0.004)\end{array}$ & $\begin{array}{c}-0.043^{* * *} \\
(0.002)\end{array}$ \\
\hline$\gamma^{2011}$ & $\begin{array}{c}-0.497^{* * *} \\
(0.016)\end{array}$ & $\begin{array}{c}-0.107^{* * *} \\
(0.009)\end{array}$ & $\begin{array}{c}-0.462^{* * *} \\
(0.007)\end{array}$ & $\begin{array}{c}-0.054^{* * *} \\
(0.002)\end{array}$ & $\begin{array}{c}-0.461^{* * *} \\
(0.004)\end{array}$ & $\begin{array}{c}-0.048^{* * *} \\
(0.002)\end{array}$ \\
\hline$\delta^{1981}$ & $\begin{array}{l}0.068^{* *} \\
(0.027)\end{array}$ & $\begin{array}{c}-0.064^{* * *} \\
(0.015)\end{array}$ & $\begin{array}{c}0.006 \\
(0.025)\end{array}$ & $\begin{array}{c}0.002 \\
(0.014)\end{array}$ & $\begin{array}{c}-0.007^{*} \\
(0.004)\end{array}$ & $\begin{array}{l}0.005^{* *} \\
(0.002)\end{array}$ \\
\hline$\delta^{1991}$ & $\begin{array}{c}-0.011 \\
(0.033)\end{array}$ & $\begin{array}{c}-0.018 \\
(0.021)\end{array}$ & $\begin{array}{c}-0.025 \\
(0.031)\end{array}$ & $\begin{array}{c}0.023 \\
(0.016)\end{array}$ & $\begin{array}{c}0.001 \\
(0.005)\end{array}$ & $\begin{array}{c}0.002 \\
(0.002)\end{array}$ \\
\hline$\delta^{2001}$ & $\begin{array}{c}0.057 \\
(0.038)\end{array}$ & $\begin{array}{c}-0.010 \\
(0.006)\end{array}$ & $\begin{array}{c}-0.037 \\
(0.032)\end{array}$ & $\begin{array}{c}0.004 \\
(0.010)\end{array}$ & $\begin{array}{c}-0.014^{* *} \\
(0.006)\end{array}$ & $\begin{array}{c}0.003 \\
(0.002)\end{array}$ \\
\hline$\delta^{2011}$ & $\begin{array}{c}-0.012 \\
(0.037)\end{array}$ & $\begin{array}{c}0.007 \\
(0.013)\end{array}$ & $\begin{array}{c}-0.074^{* *} \\
(0.032)\end{array}$ & $\begin{array}{c}-0.001 \\
(0.008)\end{array}$ & $\begin{array}{c}-0.007 \\
(0.006)\end{array}$ & $\begin{array}{l}0.004^{* *} \\
(0.002)\end{array}$ \\
\hline Number of obs. & 26,673 & 26,671 & 63,772 & 63,769 & 233,320 & 233,301 \\
\hline Number of ind. & 10,149 & 10,149 & 24,155 & 24,155 & 81,933 & 81,933 \\
\hline$R^{2}$ & 0.161 & 0.028 & 0.143 & 0.013 & 0.115 & 0.010 \\
\hline
\end{tabular}

Table 6. Differences in employment status between treated and control groups, 1981-2011. 


\begin{tabular}{|c|c|c|c|c|c|c|}
\hline & \multicolumn{2}{|c|}{$\begin{array}{c}D 1 \\
\text { (stevedores vs. } \\
\text { other occupations) }\end{array}$} & \multicolumn{2}{|c|}{$\begin{array}{c}\qquad D 2 \\
\text { (port industry vs. } \\
\text { other industries) }\end{array}$} & \multicolumn{2}{|c|}{$\begin{array}{l}D 3 \\
\text { (port district vs. } \\
\text { other districts) }\end{array}$} \\
\hline & $\begin{array}{l}\text { Model (5) } \\
\text { Retired }\end{array}$ & $\begin{array}{l}\text { Model (6) } \\
\quad \text { Sick }\end{array}$ & $\begin{array}{l}\text { Model (5) } \\
\text { Retired }\end{array}$ & $\begin{array}{l}\text { Model (6) } \\
\text { Sick }\end{array}$ & $\begin{array}{l}\text { Model (5) } \\
\text { Retired }\end{array}$ & $\begin{array}{l}\text { Model (6) } \\
\quad \text { Sick }\end{array}$ \\
\hline \multicolumn{7}{|c|}{ (a) Raw differences } \\
\hline$\alpha$ & $\begin{array}{l}0.140^{* * *} \\
(0.002)\end{array}$ & $\begin{array}{l}0.037^{* * *} \\
(0.001)\end{array}$ & $\begin{array}{l}0.140^{* * *} \\
(0.001)\end{array}$ & $\begin{array}{l}0.031^{* * *} \\
(0.001)\end{array}$ & $\begin{array}{l}0.140^{* * *} \\
(0.001)\end{array}$ & $\begin{array}{l}0.031^{\text {*** }} \\
(0.001)\end{array}$ \\
\hline$\gamma^{1991}$ & $\begin{array}{l}0.132^{* * *} \\
(0.002)\end{array}$ & $\begin{array}{l}0.041^{* * *} \\
(0.002)\end{array}$ & $\begin{array}{l}0.145^{* * *} \\
(0.002)\end{array}$ & $\begin{array}{l}0.033^{* * *} \\
(0.001)\end{array}$ & $\begin{array}{l}0.145^{* * *} \\
(0.002)\end{array}$ & $\begin{array}{l}0.032^{* * *} \\
(0.001)\end{array}$ \\
\hline$\gamma^{2001}$ & $\begin{array}{l}0.251^{* * *} \\
(0.003)\end{array}$ & $\begin{array}{l}0.078^{* * *} \\
(0.002)\end{array}$ & $\begin{array}{l}0.284^{* * *} \\
(0.002)\end{array}$ & $\begin{array}{l}0.064^{* * *} \\
(0.001)\end{array}$ & $\begin{array}{l}0.281^{* * *} \\
(0.002)\end{array}$ & $\begin{array}{l}0.064^{* * *} \\
(0.002)\end{array}$ \\
\hline$\gamma^{2011}$ & $\begin{array}{l}0.441^{* * *} \\
(0.004)\end{array}$ & $\begin{array}{l}0.010^{* * *} \\
(0.002)\end{array}$ & $\begin{array}{l}0.476^{* * *} \\
(0.003)\end{array}$ & $\begin{array}{l}0.005^{* * *} \\
(0.001)\end{array}$ & $\begin{array}{l}0.474^{* * *} \\
(0.003)\end{array}$ & $\begin{array}{l}0.006^{\text {*** }} \\
(0.001)\end{array}$ \\
\hline$\delta^{1981}$ & $\begin{array}{c}0.017 \\
(0.020)\end{array}$ & $\begin{array}{c}0.021 \\
(0.013)\end{array}$ & $\begin{array}{l}0.061^{* * *} \\
(0.021)\end{array}$ & $\begin{array}{c}0.012 \\
(0.011)\end{array}$ & $\begin{array}{c}0.004 \\
(0.003)\end{array}$ & $\begin{array}{c}0.001 \\
(0.002)\end{array}$ \\
\hline$\delta^{1991}$ & $\begin{array}{l}0.066^{* *} \\
(0.029)\end{array}$ & $\begin{array}{l}0.069^{* * *} \\
(0.022)\end{array}$ & $\begin{array}{l}0.093^{* * *} \\
(0.029)\end{array}$ & $\begin{array}{c}0.028 \\
(0.018)\end{array}$ & $\begin{array}{c}0.006 \\
(0.004)\end{array}$ & $\begin{array}{c}0.004^{*} \\
(0.002)\end{array}$ \\
\hline$\delta^{2001}$ & $\begin{array}{l}0.112^{* * *} \\
(0.036)\end{array}$ & $\begin{array}{c}0.060^{*} \\
(0.031)\end{array}$ & $\begin{array}{l}0.130^{* * *} \\
(0.035)\end{array}$ & $\begin{array}{c}0.020 \\
(0.025)\end{array}$ & $\begin{array}{l}0.025^{* * *} \\
(0.005)\end{array}$ & $\begin{array}{c}0.001 \\
(0.003)\end{array}$ \\
\hline$\delta^{2011}$ & $\begin{array}{l}0.191^{* * *} \\
(0.038)\end{array}$ & $\begin{array}{c}0.002 \\
(0.019)\end{array}$ & $\begin{array}{l}0.185^{* * *} \\
(0.035)\end{array}$ & $\begin{array}{c}-0.029^{* * *} \\
(0.008)\end{array}$ & $\begin{array}{l}0.016^{* * *} \\
(0.006)\end{array}$ & $\begin{array}{c}0.000 \\
(0.002)\end{array}$ \\
\hline $\begin{array}{l}\text { Number of obs. } \\
\text { Number of ind. } \\
R^{2}\end{array}$ & $\begin{array}{r}126,850 \\
44,964 \\
0.111\end{array}$ & $\begin{array}{r}122,643 \\
44,949 \\
0.014\end{array}$ & $\begin{array}{r}278,985 \\
98,018 \\
0.128\end{array}$ & $\begin{array}{r}268,968 \\
97,984 \\
0.012\end{array}$ & $\begin{array}{r}278,028 \\
97,657 \\
0.128\end{array}$ & $\begin{array}{r}268,048 \\
97,623 \\
0.012\end{array}$ \\
\hline (b) Matched on & 11 character & ristics & & & & \\
\hline$\alpha$ & $\begin{array}{l}0.148^{* * *} \\
(0.008)\end{array}$ & $\begin{array}{l}0.065^{* * *} \\
(0.007)\end{array}$ & $\begin{array}{l}0.205^{* * *} \\
(0.004)\end{array}$ & $\begin{array}{l}0.044^{* * *} \\
(0.002)\end{array}$ & $\begin{array}{l}0.139^{* * *} \\
(0.002)\end{array}$ & $\begin{array}{l}0.034^{* * *} \\
(0.001)\end{array}$ \\
\hline$\gamma^{1991}$ & $\begin{array}{l}0.214^{* * *} \\
(0.012)\end{array}$ & $\begin{array}{l}0.043^{* * *} \\
(0.010)\end{array}$ & $\begin{array}{l}0.202^{\text {*** }} \\
(0.005)\end{array}$ & $\begin{array}{l}0.031^{* * *} \\
(0.003)\end{array}$ & $\begin{array}{l}0.150^{* * *} \\
(0.003)\end{array}$ & $\begin{array}{l}0.039^{* * *} \\
(0.002)\end{array}$ \\
\hline$\gamma^{2001}$ & $\begin{array}{l}0.394^{* * *} \\
(0.016)\end{array}$ & $\begin{array}{l}0.113^{* * *} \\
(0.016)\end{array}$ & $\begin{array}{l}0.360^{* * *} \\
(0.006)\end{array}$ & $\begin{array}{l}0.067^{* * *} \\
(0.004)\end{array}$ & $\begin{array}{l}0.291^{\text {*** }} \\
(0.004)\end{array}$ & $\begin{array}{l}0.073^{* * *} \\
(0.003)\end{array}$ \\
\hline$\gamma^{2011}$ & $\begin{array}{l}0.589^{* * *} \\
(0.017)\end{array}$ & $\begin{array}{c}-0.015 \\
(0.013)\end{array}$ & $\begin{array}{l}0.511^{* * *} \\
(0.007)\end{array}$ & $\begin{array}{c}-0.011^{* * *} \\
(0.003)\end{array}$ & $\begin{array}{c}0.489^{* * *} \\
(0.004)\end{array}$ & $\begin{array}{l}0.006^{* * *} \\
(0.002)\end{array}$ \\
\hline$\delta^{1981}$ & $\begin{array}{c}0.001 \\
(0.021)\end{array}$ & $\begin{array}{r}-0.002 \\
(0.016)\end{array}$ & $\begin{array}{r}-0.005 \\
(0.022)\end{array}$ & $\begin{array}{c}-0.000 \\
(0.011)\end{array}$ & $\begin{array}{c}0.005 \\
(0.003)\end{array}$ & $\begin{array}{c}-0.002 \\
(0.002)\end{array}$ \\
\hline$\delta^{1991}$ & $\begin{array}{c}-0.019 \\
(0.033)\end{array}$ & $\begin{array}{c}0.040^{*} \\
(0.024)\end{array}$ & $\begin{array}{c}-0.024 \\
(0.030)\end{array}$ & $\begin{array}{c}0.019 \\
(0.018)\end{array}$ & $\begin{array}{c}0.003 \\
(0.005)\end{array}$ & $\begin{array}{c}-0.006^{* *} \\
(0.003)\end{array}$ \\
\hline$\delta^{2001}$ & $\begin{array}{c}-0.045 \\
(0.041)\end{array}$ & $\begin{array}{c}0.006 \\
(0.037)\end{array}$ & $\begin{array}{c}-0.005 \\
(0.036)\end{array}$ & $\begin{array}{c}0.006 \\
(0.026)\end{array}$ & $\begin{array}{l}0.019^{* * *} \\
(0.006)\end{array}$ & $\begin{array}{c}-0.011^{* * *} \\
(0.004)\end{array}$ \\
\hline$\delta^{2011}$ & $\begin{array}{c}0.024 \\
(0.044)\end{array}$ & $\begin{array}{c}0.004 \\
(0.024)\end{array}$ & $\begin{array}{l}0.095^{* * *} \\
(0.035)\end{array}$ & $\begin{array}{c}-0.025^{* * *} \\
(0.008)\end{array}$ & $\begin{array}{c}0.005 \\
(0.007)\end{array}$ & $\begin{array}{c}-0.003 \\
(0.003)\end{array}$ \\
\hline Number of obs. & 26,670 & 25,589 & 63,767 & 60,708 & 233,298 & 224,808 \\
\hline Number of ind. & 10,149 & 10,146 & 24,155 & 24,147 & 81,933 & 81,908 \\
\hline$R^{2}$ & 0.180 & 0.025 & 0.158 & 0.017 & 0.135 & 0.013 \\
\hline
\end{tabular}

Table 7. Differences in retirement and sickness status between treated and control groups, 1981-2011. 
Two points are striking about the raw differences in employment outcomes. First, in sample $D 1$, large gaps only emerge from 1991 onwards. In fact, employment rates for stevedores are insignificantly different from those for the control group in 1981 ( $\delta^{1981}=$ -0.009 with a standard error of 0.024$)$; unemployment rates for stevedores are actually 2.5pp lower than the control group. In contrast, a negative employment gap has already emerged in 1981 for samples D2 and D3. This result is entirely consistent with the pattern of industrial relations described in Section 2. The National Dock Labour Scheme prevented any involuntary redundancy for stevedores until 1989. Second, differences in employment outcomes are very long-lasting, with significant differences in employment rates and retirement rates even up to 2011.

Panel (b) in Tables 6 and 7 repeats the analysis after matching. As before, matching greatly changes the composition of the control group. For example, in sample $D 1$ the unmatched control group have an employment rate in 1981 of 0.741 ; the same employment rate for the matched control group is 0.666. Similarly, the matched control group have higher rates of unemployment, retirement and disability. As a result the DiD estimates become much smaller and in most cases are no longer significantly different from zero. It is particularly noticeable that, in sample $D 1$, estimates of $\delta^{1981}$ are now positive for employment (0.068 with a standard error of 0.027$)$ and negative for unemployment ( -0.064 with a standard error of 0.015). Employment guarantees clearly worked for stevedores compared to the matched control group. More surprisingly, estimates of $\delta^{1991}, \delta^{2001}$ and $\delta^{2011}$ are generally small and insignificantly different from zero. Overall, employment rates for stevedores were no lower in subsequent years than for the matched control group. In part, this reflects the extremely poor employment performance of unskilled men during the period, as documented in for example Nickell and Bell (1995). Results from the D2 sample are generally less favourable, with some evidence of lower employment rates and higher rates of retirement. The $D 2$ treatment group were affected by the loss of employment in port industries, but did not have the same employment guarantees as the $D 1$ treatment group. The results from sample $D 3$ suggest only very small differences in employment and unemployment for workers whose employment is near ports, and who are not themselves stevedores or in the port industry.

\subsection{Geographical and occupational movement}

One possible effect of containerisation is to force workers to move to different geographical areas, or to change occupation. The LS includes an indicator for whether the respondent is living at a different address as 10 years previously, and we use this as our dependent variable for Model (7). Results are shown in Table 8.

Estimates of $\alpha$ in panel (a) show that about half of the control group changed address in the 10 years between 1971 and 1981. Estimates of $\gamma^{s}$ then show that the probability of changing address declines in the control group over each of the following 10 year intervals, 


\begin{tabular}{|c|c|c|c|c|c|c|}
\hline & \multicolumn{2}{|c|}{$\begin{array}{c}D 1 \\
\text { (stevedores vs. } \\
\text { other occupations) }\end{array}$} & \multicolumn{2}{|c|}{$\begin{array}{c}D 2 \\
\text { (port industry vs. } \\
\text { other industries) }\end{array}$} & \multicolumn{2}{|c|}{$\begin{array}{c}\text { D3 } \\
\text { (port district vs. } \\
\text { other districts) }\end{array}$} \\
\hline & $\begin{array}{l}\text { Model (7) } \\
\text { Moved in } \\
\text { last } 10 \\
\text { years }\end{array}$ & $\begin{array}{l}\text { Model }(8) \\
\text { Changed } \\
\text { occ. in last } \\
10 \text { years }\end{array}$ & $\begin{array}{l}\text { Model (7) } \\
\text { Moved in } \\
\text { last } 10 \\
\text { years }\end{array}$ & $\begin{array}{l}\text { Model }(8) \\
\text { Changed } \\
\text { occ. in last } \\
10 \text { years }\end{array}$ & $\begin{array}{l}\text { Model }(7) \\
\text { Moved in } \\
\text { last } 10 \\
\text { years }\end{array}$ & $\begin{array}{l}\text { Model }(8) \\
\text { Changed } \\
\text { occ. in last } \\
10 \text { years }\end{array}$ \\
\hline \multicolumn{7}{|c|}{ (a) Raw differences } \\
\hline$\alpha$ & $\begin{array}{l}0.519^{* * *} \\
(0.002)\end{array}$ & $\begin{array}{l}0.619^{* * *} \\
(0.003)\end{array}$ & $\begin{array}{l}0.553^{* * *} \\
(0.002)\end{array}$ & $\begin{array}{l}0.627^{* * *} \\
(0.002)\end{array}$ & $\begin{array}{l}0.551^{* * *} \\
(0.002)\end{array}$ & $\begin{array}{l}0.630^{* * *} \\
(0.002)\end{array}$ \\
\hline$\gamma^{1991}$ & $\begin{array}{c}-0.135^{* * *} \\
(0.003)\end{array}$ & $\begin{array}{c}-0.074^{* * *} \\
(0.004)\end{array}$ & $\begin{array}{c}-0.134^{* * *} \\
(0.002)\end{array}$ & $\begin{array}{c}-0.070^{* * *} \\
(0.003)\end{array}$ & $\begin{array}{c}-0.131^{* * *} \\
(0.002)\end{array}$ & $\begin{array}{c}-0.070^{* * *} \\
(0.003)\end{array}$ \\
\hline$\gamma^{2001}$ & $\begin{array}{c}-0.231^{* * *} \\
(0.004)\end{array}$ & $\begin{array}{c}-0.015^{* * *} \\
(0.005)\end{array}$ & $\begin{array}{c}-0.245^{* * *} \\
(0.002)\end{array}$ & $\begin{array}{c}-0.002 \\
(0.004)\end{array}$ & $\begin{array}{c}-0.245^{* * *} \\
(0.003)\end{array}$ & $\begin{array}{c}-0.005 \\
(0.004)\end{array}$ \\
\hline$\gamma^{2011}$ & $\begin{array}{c}-0.296^{* * *} \\
(0.004)\end{array}$ & & $\begin{array}{c}-0.320^{* * *} \\
(0.003)\end{array}$ & & $\begin{array}{c}-0.318^{* * *} \\
(0.003)\end{array}$ & \\
\hline$\delta^{1981}$ & $\begin{array}{c}-0.022 \\
(0.027)\end{array}$ & $\begin{array}{c}-0.167^{* * *} \\
(0.031)\end{array}$ & $\begin{array}{c}-0.084^{* * *} \\
(0.027)\end{array}$ & $\begin{array}{c}-0.065^{* *} \\
(0.032)\end{array}$ & $\begin{array}{l}0.009^{* *} \\
(0.004)\end{array}$ & $\begin{array}{c}-0.017^{* * *} \\
(0.005)\end{array}$ \\
\hline$\delta^{1991}$ & $\begin{array}{c}-0.016 \\
(0.030)\end{array}$ & $\begin{array}{l}0.147^{* * *} \\
(0.045)\end{array}$ & $\begin{array}{c}-0.077^{* * *} \\
(0.030)\end{array}$ & $\begin{array}{c}0.011 \\
(0.047)\end{array}$ & $\begin{array}{r}-0.009^{*} \\
(0.005)\end{array}$ & $\begin{array}{c}-0.017^{* * *} \\
(0.006)\end{array}$ \\
\hline$\delta^{2001}$ & $\begin{array}{c}-0.035 \\
(0.032)\end{array}$ & $\begin{array}{c}-0.104 \\
(0.072)\end{array}$ & $\begin{array}{r}-0.054^{*} \\
(0.031)\end{array}$ & $\begin{array}{c}0.041 \\
(0.066)\end{array}$ & $\begin{array}{c}0.008 \\
(0.005)\end{array}$ & $\begin{array}{c}0.006 \\
(0.008)\end{array}$ \\
\hline$\delta^{2011}$ & $\begin{array}{c}-0.003 \\
(0.039)\end{array}$ & & $\begin{array}{r}-0.002 \\
(0.038)\end{array}$ & & $\begin{array}{r}-0.004 \\
(0.005)\end{array}$ & \\
\hline Number of obs. & 121,957 & 61,634 & 267,832 & 138,118 & 266,899 & 137,716 \\
\hline Number of ind. & 44,277 & 32,948 & 96,570 & 73,636 & 96,212 & 73,391 \\
\hline$R^{2}$ & 0.053 & 0.005 & 0.060 & 0.004 & 0.060 & 0.004 \\
\hline \multicolumn{7}{|c|}{ (b) Matched on 1971 characteristics } \\
\hline$\alpha$ & $\begin{array}{l}0.524^{* * *} \\
(0.012)\end{array}$ & $\begin{array}{l}0.701^{* * *} \\
(0.014)\end{array}$ & $\begin{array}{l}0.501^{* * *} \\
(0.004)\end{array}$ & $\begin{array}{l}0.616^{* * *} \\
(0.005)\end{array}$ & $\begin{array}{l}0.565^{\text {*** }} \\
(0.003)\end{array}$ & $\begin{array}{c}0.626^{* * *} \\
(0.003)\end{array}$ \\
\hline$\gamma^{1991}$ & $\begin{array}{c}-0.176^{* * *} \\
(0.016)\end{array}$ & $\begin{array}{c}-0.104^{* * *} \\
(0.022)\end{array}$ & $\begin{array}{c}-0.127^{* * *} \\
(0.006)\end{array}$ & $\begin{array}{c}-0.062^{* * *} \\
(0.007)\end{array}$ & $\begin{array}{c}-0.152^{* * *} \\
(0.004)\end{array}$ & $\begin{array}{c}-0.070^{* * *} \\
(0.005)\end{array}$ \\
\hline$\gamma^{2001}$ & $\begin{array}{c}-0.228^{* * *} \\
(0.018)\end{array}$ & $\begin{array}{c}-0.088^{* * *} \\
(0.026)\end{array}$ & $\begin{array}{c}-0.210^{\text {*** }} \\
(0.006)\end{array}$ & $\begin{array}{c}0.021^{* *} \\
(0.010)\end{array}$ & $\begin{array}{c}-0.265^{* * *} \\
(0.004)\end{array}$ & $\begin{array}{c}-0.005 \\
(0.006)\end{array}$ \\
\hline$\gamma^{2011}$ & $\begin{array}{c}-0.279^{* * *} \\
(0.019)\end{array}$ & & $\begin{array}{c}-0.270^{* * *} \\
(0.007)\end{array}$ & & $\begin{array}{c}-0.336^{* * *} \\
(0.004)\end{array}$ & \\
\hline$\delta^{1981}$ & $\begin{array}{c}-0.020 \\
(0.030)\end{array}$ & $\begin{array}{c}-0.243^{* * *} \\
(0.036)\end{array}$ & $\begin{array}{r}-0.042 \\
(0.027)\end{array}$ & $\begin{array}{r}-0.058^{*} \\
(0.033)\end{array}$ & $\begin{array}{c}-0.010^{* *} \\
(0.005)\end{array}$ & $\begin{array}{c}-0.014^{* * *} \\
(0.005)\end{array}$ \\
\hline$\delta^{1991}$ & $\begin{array}{c}0.021 \\
(0.034)\end{array}$ & $\begin{array}{c}0.112^{* *} \\
(0.050)\end{array}$ & $\begin{array}{r}-0.030 \\
(0.030)\end{array}$ & $\begin{array}{c}0.022 \\
(0.048)\end{array}$ & $\begin{array}{c}-0.004 \\
(0.005)\end{array}$ & $\begin{array}{r}-0.014^{*} \\
(0.007)\end{array}$ \\
\hline$\delta^{2001}$ & $\begin{array}{c}-0.048 \\
(0.037)\end{array}$ & $\begin{array}{c}-0.090 \\
(0.079)\end{array}$ & $\begin{array}{c}-0.034 \\
(0.032)\end{array}$ & $\begin{array}{c}0.024 \\
(0.068)\end{array}$ & $\begin{array}{c}0.013^{* *} \\
(0.006)\end{array}$ & $\begin{array}{c}0.008 \\
(0.009)\end{array}$ \\
\hline$\delta^{2011}$ & $\begin{array}{c}-0.005 \\
(0.046)\end{array}$ & & $\begin{array}{c}0.005 \\
(0.039)\end{array}$ & & $\begin{array}{c}-0.001 \\
(0.006)\end{array}$ & \\
\hline Number of obs. & 25,545 & 11,543 & 61,272 & 28,578 & 223,933 & 115,607 \\
\hline Number of ind. & 9,938 & 6,910 & 23,765 & 16,747 & 80,711 & 61,784 \\
\hline$R^{2}$ & 0.050 & 0.049 & 0.040 & 0.005 & 0.064 & 0.005 \\
\hline
\end{tabular}

Table 8. Differences in geographical and occupational mobility between treated and control groups, 1981-2011 
which in part reflects the aging of the sample. For example, the probability of changing address falls to $38 \%$ between 1981 and 1991 (0.519-0.135) and 22\% between 2001 and 2011 (0.519-0.296). Similar patterns are observed in the control group for samples D2 and $D 3$. The estimates of $\delta^{s}$ in sample $D 1$ are negative, but all insignificantly different from zero. This is true both in the raw data (panel a) and after matching (panel b). In other words, stevedores in 1971 did not exhibit any greater tendency to change address in any of the subsequent decades up to 2011. Thus, despite the dramatic decline in jobs for stevedores in this period, there appears to have been no additional geographic mobility response at all. This result is consistent with the well-established result that geographic mobility in response to shocks is small, in particular among less-skilled workers (e.g. Bound and Holzer, 2000). In sample D2 there is some evidence of lower geographic mobility (estimates of $\delta^{s}$ are all negative), but this effect largely disappears in panel (b) after matching. In sample $D 3$ there does not appear to be a consistent difference between the treatment and control group after matching: we find somewhat lower mobility rates between 1971 and $1981\left(\delta^{1981}=-0.01\right)$, but somewhat higher rates between 1991 and $2001\left(\delta^{2001}=0.013\right)$. These effects are also very small when compared to the proportion of the control group who move. Thus overall we find no evidence of increased mobility as a result of the dramatic reductions in port employment.

Finally in Model (8) we consider occupational mobility. Measuring occupational mobility is more complex because of numerous changes in occupational coding between 1971-2011. However, in each census in the LS occupation is coded using the same classification as in the previous census, so for Model (8) we construct an indicator (for those in employment) which takes the value 1 if the individual has changed occupation in the previous 10 years. The sample here consists only of individuals who are observed in employment in consecutive censuses, and this variable is not available in 2011 because of changes to occupational definitions. Changes in occupation are very common: in the control group $62 \%$ of the sample change occupation in 1981 as in 1971 ( $\alpha=0.619)$, and this decreases slightly to 55\% between 1981 and 1991 and $53 \%$ between 1991 and 2001. Looking at the matching results in panel (b), and as we would expect for sample $D 1$, there is a very strong effect of containerisation on occupation, but again tempered by the effect of employment protection. For $D 1$ the treatment group are less likely to change occupation between 1971 and $1981\left(\delta^{1981}=-0.243\right.$ in $\left.D 1\right)$. This switches to a large positive effect for stevedores between 1981 and $1991\left(\delta^{1991}=0.112\right.$ in $\left.D 1\right)$ which is consistent with the fact that employment guarantees were removed in 1989 (see Section 2). It is noticeable that the same result does not occur for $D 2$, suggesting that port industry workers as a whole were less affected by the new technology than stevedores in particular. The hypothesis that stevedores or port workers were subsequently sorted into less stable jobs is not borne out. Estimates of $\delta^{2001}$ are insignificantly different from zero for both $D 1$ and $D 2$, showing that the change in occupations which occurred between 1981 and 1991 did not continue. The results for sample D3 suggest that wide 
geographical effects are much weaker.

\subsection{Robustness checks}

In this section we consider a number of sub-samples to examine whether our results are robust. First, we consider whether the effects of containerisation on stevedores differ according to their initial socio-economic group. Socio-economic group is determined by a combination of occupation and employment status (Hattersley and Creeser, 1995). Unskilled workers who have some supervisory role (foremen) are classified as "skilled manual"; Table 3 shows that $23 \%$ of stevedores are classified as skilled manual. In Figure 6 we graphically compare the $D 1$ results from the full sample with those when we consider only workers who have no supervisory role i.e. the less skilled, or less senior. Figure 6 show that restricting the sample to less-skilled manual workers makes little difference to our conclusions. Estimated effects are always within the $95 \%$ confidence interval of the full sample. The treatment group are still more likely to appear in the linked census in subsequent years, they have lower mortality rates, higher employment rates and lower unemployment rates in 1981. Patterns of occupational mobility are almost identical to those in the full sample. Thus, it appears that the employment guarantees in place protected all stevedores and not just those in more senior positions.

Our second robustness check deals with the age of the original sample. Recall that the average age of the main sample $D 1$ was 43 , which means that a large fraction of the sample will have reached retirement age by 2011. In Figure 7 we show the effect of restricting the $D 1$ sample to workers who are between 16 and 30 years old in 1971 . Comparing the results with the results in the main sample, we observe that the positive outcomes in 1981 are even stronger for the younger sample. That is, young stevedores were even more likely to still be in employment in 1981, less likely to be unemployed, and less likely to change occupation. This last result is particularly striking, since one might hypothesise that switching occupation is more likely for younger workers when faced with a shock which reduces labour demand. However, note that we are comparing young stevedores in 1971 with a matched sample of non-stevedores who are also young. Younger workers have higher rates of occupational mobility in general, but the job guarantees allowed stevedores to remain in the same occupation between 1971 and 1981.

Our third robustness check considers particular locations. London and Liverpool were the largest two ports in England and Wales before containerisation both in terms of foreign tonnage and employment. Following containerisation, all of the London docks (except Tilbury) shut down while Liverpool was refurbished to accommodate containers but lost its leading position to Felixstowe and Southampton (see Section 2). In Figure 8 we report our estimates of the effects of containerisation when the treatment group in the D1 sample is restricted only to those stevedores who worked in London or Liverpool in 1971. While there are some differences in the coefficient estimates, in almost every case 

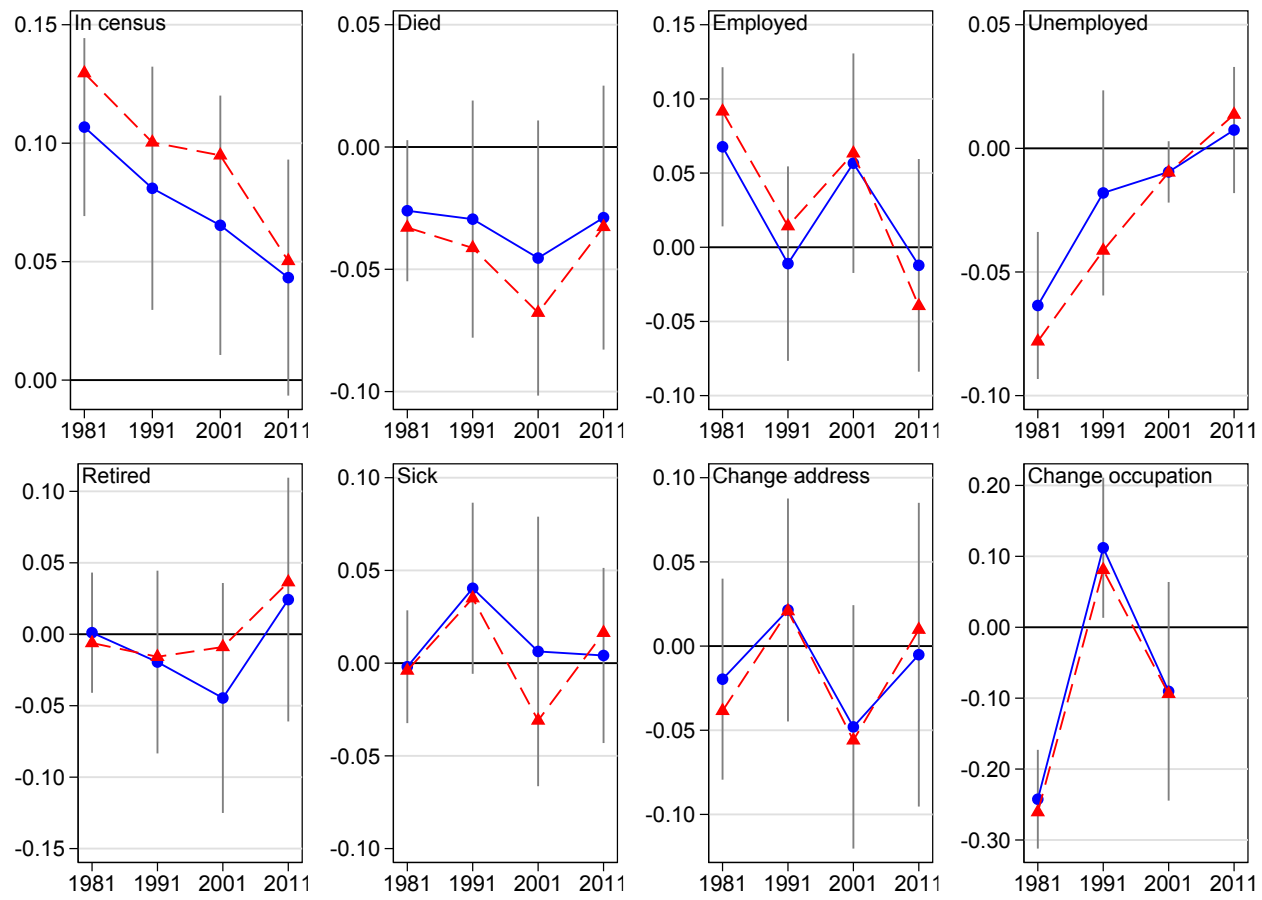

Figure 6. DiD estimates of $\delta^{1981} \ldots \delta^{2011}$ from (2) using comparison $D 1$ (stevedores vs. non-stevedores). Samples are matched on characteristics in 1971. _—_ are estimates using the full sample. - $-\mathbf{\Delta}--$ are estimates using only unskilled manual workers. For clarity, $95 \%$ confidence interval is plotted only for the full sample.
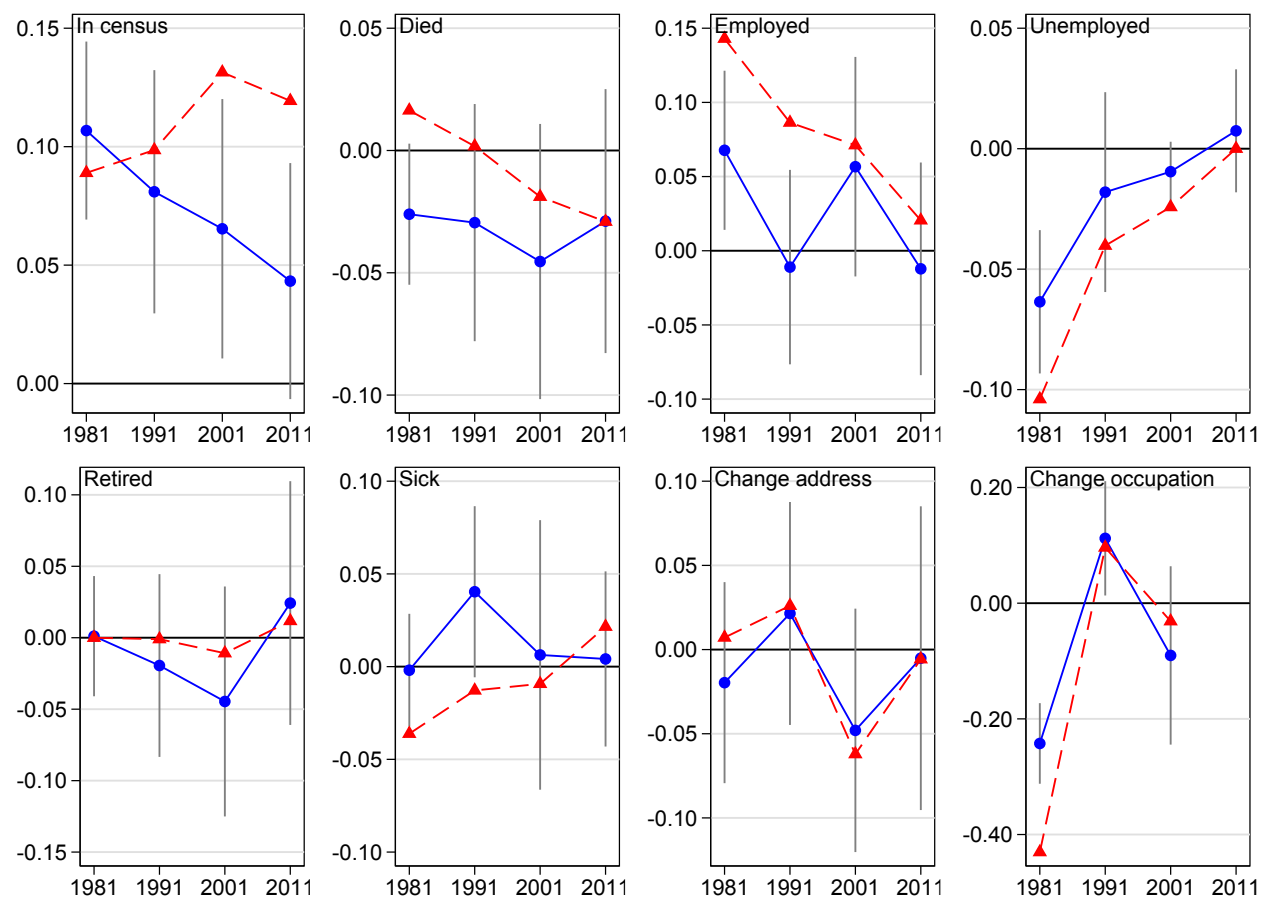

Figure 7. DiD estimates of $\delta^{1981} \ldots \delta^{2011}$ from (2) using comparison $D 1$ (stevedores vs. non-stevedores). Samples are matched on characteristics in 1971. —— are estimates from the full sample. $--\boldsymbol{\Delta}_{-}-$are estimates using only workers aged $\leq 30$ in 1971 . For clarity, $95 \%$ confidence interval is plotted only for the full sample. 

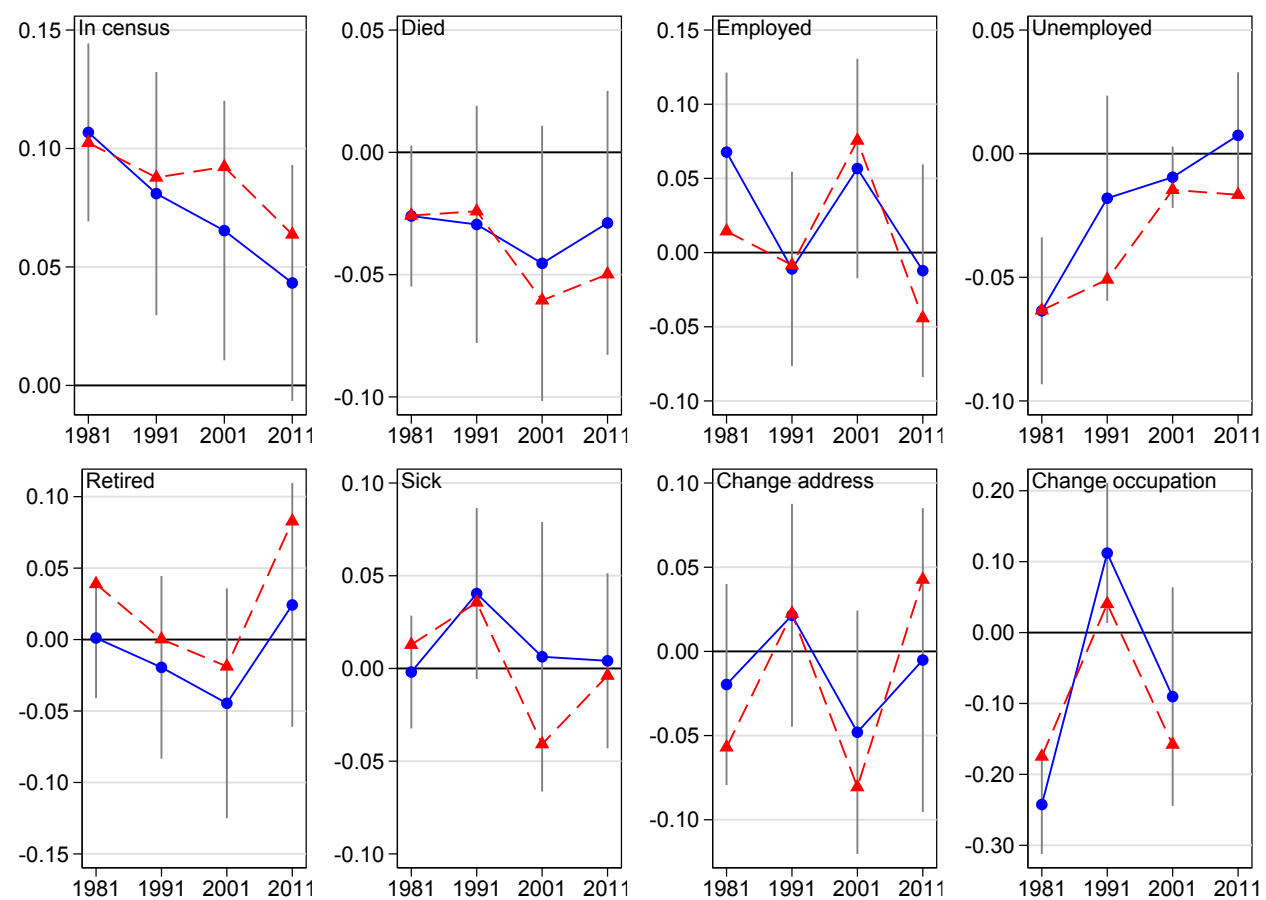

Figure 8. DiD estimates of $\delta^{1981} \ldots \delta^{2011}$ from (2) using comparison $D 1$ (stevedores vs. non-stevedores). Samples are matched on characteristics in 1971. —— are estimates from the full sample. $-\mathbf{-}--$ are estimates restricting the treatment group to include only stevedores in London and Liverpool in 1971. For clarity, 95\% confidence interval is plotted only for the full sample.

the estimates for the restricted sample lie within the confidence interval of the estimates from the full sample. Stevedores in London and Liverpool do not have such positive employment effects in 1981, largely as a result of higher rates of retirement, but overall patterns are very similar for this geographic sub-group.

Our final robustness check considers in more detail the geographical comparisons of sample D3. To make the distinction between the geographically defined treatment and control groups more clear-cut, we define two alternative control groups. In $D 3 a$ we include in the control group only workers whose place of work is in Counties which do not contain any major ports. ${ }^{26}$ Thus for example all workers in London are excluded from this control group. In $D 3 b$ we include in the control group only workers whose place of work is at least $20 \mathrm{~km}$ from any port. ${ }^{27}$ We do this because it seems that the basic geographic control group $D 3=0$ may include workers who are affected by the process of containerisation because their place of work is near a port, even if it is not in a district which includes a port. Figure 9 shows a comparison between the $D 3$, $D 3 a$ and $D 3 b$ samples. It is clear that the results from the $D 3$ and $D 3 b$ samples are very similar. Geographical differences are small and usually insignificantly different from zero. Restricting the control group to include workers whose place of work is in a County without any port does have some effect on the results, but it remains the case that any 

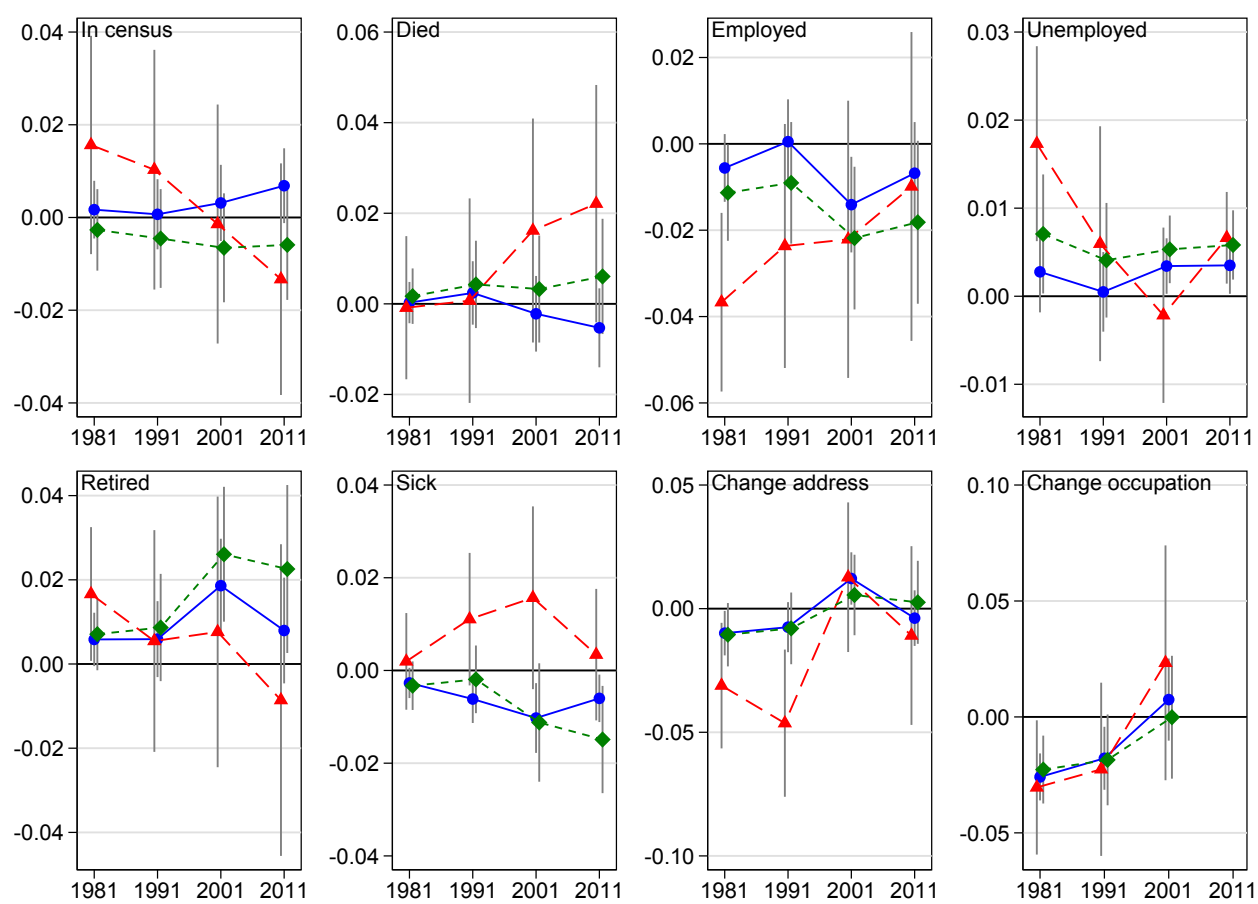

Figure 9. Figure plots DiD estimates of $\delta^{1981} \ldots \delta^{2011}$ from (2) using comparison D3 (port districts vs. non-port districts). Samples are matched on characteristics in 1971. are estimates from $D 3 . \quad--\mathbf{A}_{-}-$are estimates restricting the control group to include only workers in counties which do not contain a major port $(D 3 a)$. ------- are estimates restricting the control group to include only workers in districts more than $20 \mathrm{~km}$ from any port $(D 3 b)$.

differences are small compared to those from samples $D 1$ and $D 2$.

\subsection{Summary}

Figure 10 summarises our estimates of the impact of containerisation. Each panel shows estimates of $\delta^{1981} \ldots \delta^{2011}$ for each of the three comparisons across all eight outcomes. The matched comparison of stevedores with non-stevedores $(D 1)$ produces the strongest results for most outcomes. In particular, the negative (i.e. lower) unemployment effect and the negative occupational mobility effect in 1981 are only found for the $D 1$ comparison. Port workers and workers in port districts did not experience a similar degree of job security in 1981, which is consistent with the fact that the Dock Labour Scheme provided strong employment protection. The removal of the Dock Labour Scheme in 1989 caused a significant increase in occupational mobility in 1991 (and to a smaller extent, an increase in residential mobility). Again, these effects are seen only for the comparison of stevedores and non-stevedores. Of particular interest, however, are the long-run effects. There is no evidence here that stevedores suffered worse labour market outcomes in 2001 or 2011. 

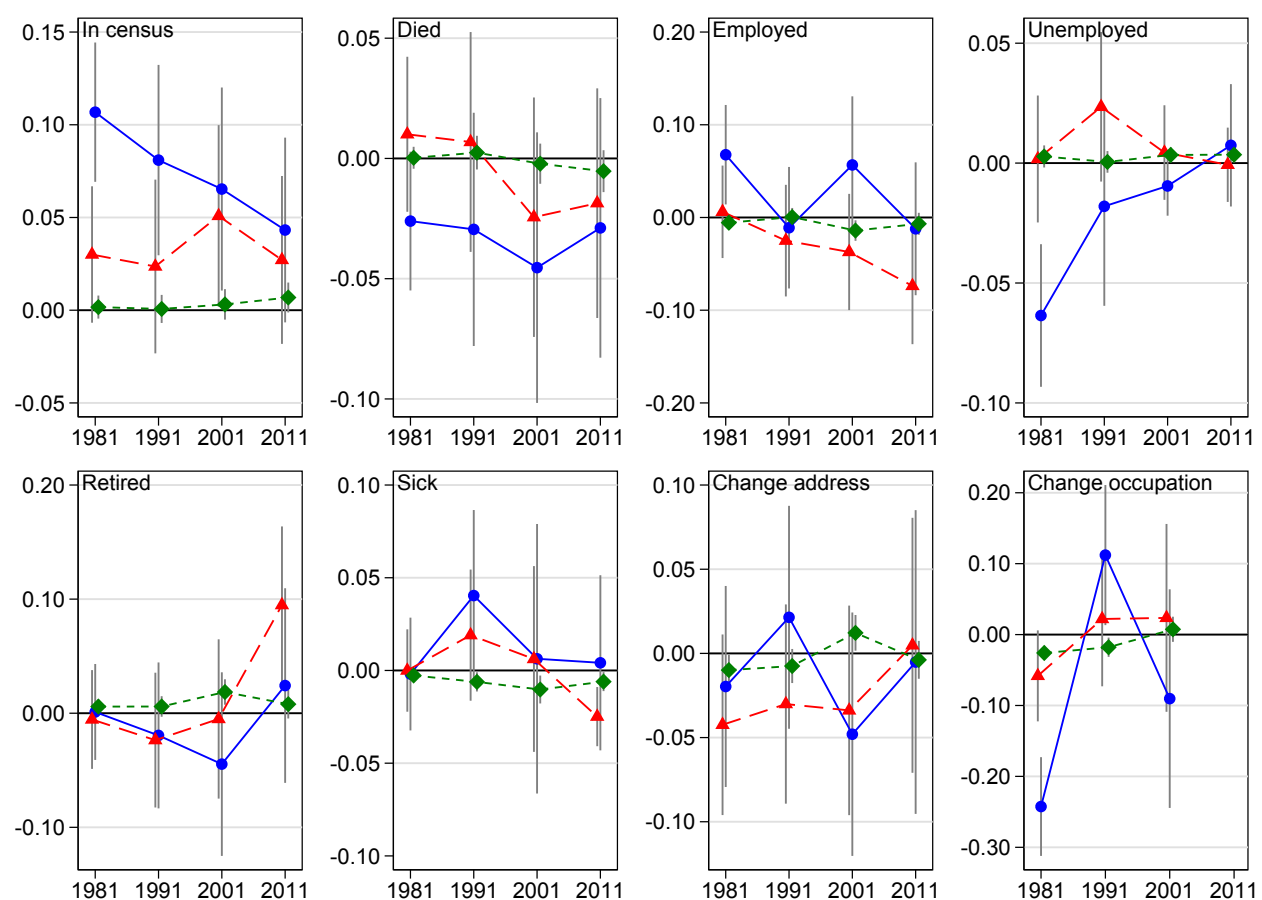

Figure 10. DiD estimates of $\delta^{1981} \ldots \delta^{2011}$ from (2). Samples are matched on characteristics in 1971. — are estimates from the $D 1$ comparison (stevedores vs. non-stevedores).

- $-\boldsymbol{\Delta}$ - - are estimates from the $D 2$ comparison (port workers vs. non-port workers).

------ are estimates from the D3 comparison (port districts vs. non-port districts).

Estimates from the $D 2$ sample of port workers and non-port workers are a useful comparison, because the $D 2$ treatment group were not protected by the NDLS. Port workers who were not stevedores in 1971 did experience lower employment rates than the control group from 1991 onwards, although the effects are only significant in 2011. The lower employment rate is accounted for entirely by a higher retirement rate rather than a higher unemployment rate. Note that this is a DiD comparison with a matched control group who are, on average, a similar age. So, this retirement effect is over and above that which we would expect given the aging of the sample. Estimates from the D3 comparison of workers in port districts and non-port districts are much more precise (because we have much larger samples), but also much smaller. There is no evidence that workers in port districts experienced different long-term labour market outcomes than a matched control group of workers in non-port districts.

\section{Conclusion}

Containerisation provides us with an opportunity to examine the labour market consequences of a technological shock which, in the space of a few years, completely removed the demand for a particular occupation. Linked census data enables us to track the workers in affected occupations and industries over the long-run, and to shed light on 
the process of adjustment. We have documented that stevedores and the port industry did suffer massive falls in demand for labour between the late 1960s and early 1980s. We have also shown that the districts containing ports experienced worse labour market outcomes which continued and have remained for over 30 years.

However, our worker-level analysis reveals a different picture. After matching stevedores and port-industry workers to observably similar unskilled men in other occupations and industries, we find that subsequent differences in labour market outcomes, mortality and mobility are typically small, insignificantly different from zero and even in some cases positive. Positive differences are most notable in 1981, at which point stevedores were protected from redundancy by the National Dock Labour Scheme. At this point stevedores faced lower unemployment rates and had lower rates of occupational mobility. When we consider port workers who were not stevedores (and therefore not protected by the Dock Labour Scheme), these positive effects in 1981 disappear. Perhaps more surprisingly, even after employment protection was removed there are not large differences in labour market outcomes between the treatment and control groups. Thus, we can conclude that workers who were stevedores or who worked in the port industry in 1971 did not suffer long-term disadvantage in the labour market over the rest of their working lives.

How can we reconcile the dramatic falls in employment documented in Figure 2 with the fact that stevedores did not change occupation between 1971 and 1981, or experience increases in unemployment? The solution lies in the fact that net changes in employment within an occupation can be accommodated by very different gross worker flows. This is illustrated in Figure 11. We take a list of all manual occupations in 1971 which have a one-to-one correspondence with an occupation in $1981 .^{28}$ For each occupation we use the LS to calculate the net change in employment and the gross inflow and outflow of workers. Figure 11 shows that the great majority of these manual occupations experienced large falls in employment between 1971 and 1981. Stevedores experienced a fall in employment of almost $50 \%$, but there are other occupations whose fall in employment was even greater. More importantly, Figure 11 shows that stevedores had low inflow and low outflow rates. Of the 36 occupations in Figure 11 stevedores have the lowest inflow rate and the sixth lowest outflow rate. Therefore when we compare the labour market performance of stevedores with other manual workers, we find that stevedores have lower rates of occupational change and unemployment.

Our results provide a contrast to the findings of Autor et al. (2014), who show that the shock of increased import competition from China had large and long-lasting effects on employment and earnings for incumbent workers in import-competing industries. However, our results should be interpreted in the light of the unique industrial relations policies which existed for this particular group of workers at the time of the shock. Dock workers were insulated from redundancy for a long time after the technological shock by strong unions which negotiated long-lasting job guarantees for the members. This itself 


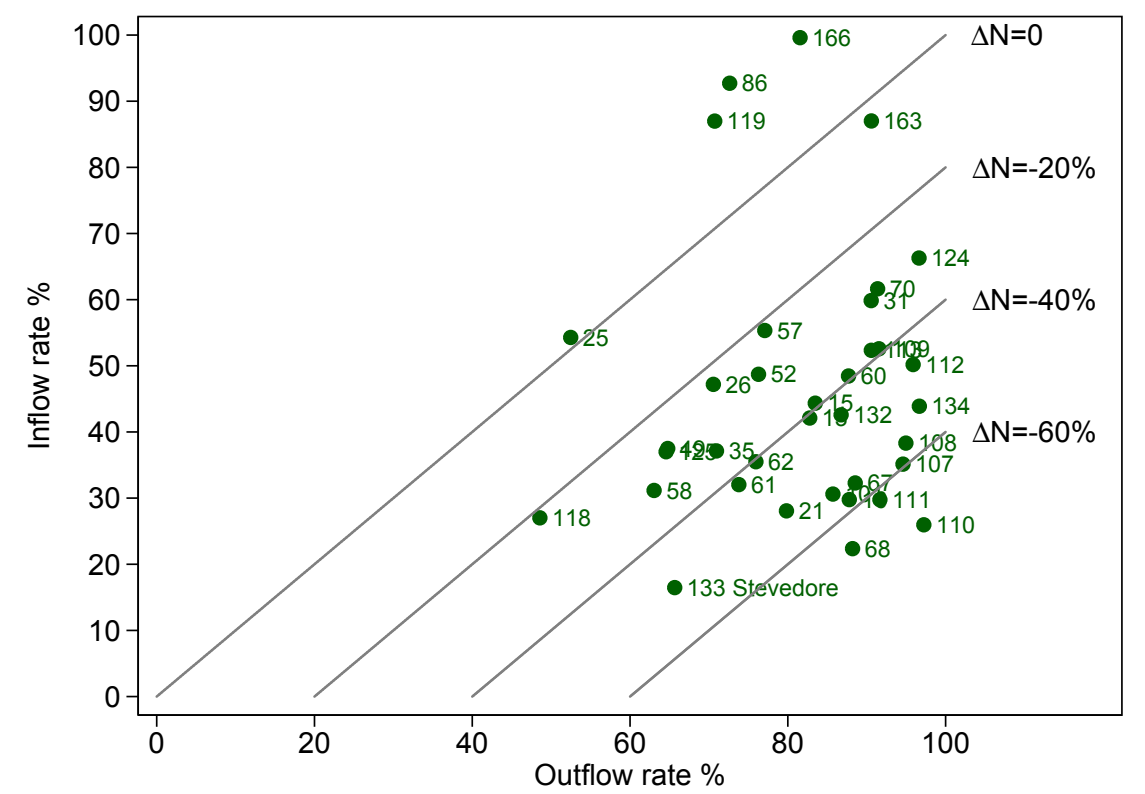

Figure 11. Inflow rate and change in employment of manual occupations 1971-1981. Diagonal lines indicate particular rates of proportional employment change. Occupation codes are those used in the 1971 census; see http://www.ucl.ac.uk/celsius/celsiusdd for a list. Source: ONS Longitudinal Study.

had consequences for the development of new ports in the UK, such that port activity shifted and concentrated in entirely new locations. One might therefore be concerned that the employment protection merely delayed and possibly amplified the eventual costs in terms of lost jobs. However, this does not appear to be the case because our estimates for 1991-2011 are also typically small or insignificant for all employment outcomes and for mortality.

The results carry interesting policy and welfare implications. They suggest that, in this case, a job protection system does not simply delay the costs of job destruction to the most vulnerable workers, but can actually reduce these costs in the long term. Of course, it also likely that this job protection system had costs to the industry and to other workers who were not protected.

There are several important caveats. First, we recognise that the process of containerisation and the associated fall in demand for stevedores began before 1971. Unfortunately, linked census data before 1971 is not available. Our treatment group is therefore a selected sample of workers who remained in that occupation or industry even after it became apparent that their work was changing and their jobs disappearing. However, one might argue that this would bias our results towards finding large negative subsequent labour market outcomes if those workers who did not have better outside opportunities were the ones to remain as stevedores in 1971. 
Second, is it possible that the adjustment process is fast enough that the 10-year intervals from census data miss much of the effect? The existing literature on displaced workers suggests not. Although the literature typically regards the "long-run" as being within 10 years of job loss, the consensus is that losses are still evident at that point. However, results from the US suggest that most of these losses come in the form of wages rather than employment differentials. It therefore seems possible that the men in our sample are suffering wage losses rather than employment losses. ${ }^{29}$

The final issue is the extent to which one can regard the various control groups we use as suitable counterfactuals for the treatment group. A profound technological shock such as the invention of containers has consequences far beyond the narrow treatment and control groups as defined here. For example, containerisation may have had a role to play in the growth in world trade which occurred over this period (Bernhofen et al., 2016) which itself affected labour market outcomes more generally (Autor et al., 2014). It is well-known that unskilled workers in general had extremely poor labour market outcomes during the 1980s and 1990s (Nickell and Bell, 1995), and this is clear in the estimated effects for our control group. Our final conclusion must therefore be that stevedores and workers in the port industry fared "no worse" than similar workers in other occupations and industries, rather than actually doing well.

\section{Notes}

${ }^{1}$ Studies for the US are consistent with the size of losses, and include Ruhm (1991), Jacobson et al. (1993) and more recently Couch and Placzek (2010) and Davis and von Wachter (2011).

2 "Containerisable trade" is defined as total trade (exports and imports) that is suitable for transport in containers and accounts for around 30\% of all UK trade by tonnage in 1970.

${ }^{3}$ As a large open island economy, the UK was heavily dependent on shipping for its trade. The UK moved 99 percent of its trade by sea in the 1960s and 1970s (Bernhofen et al. (2016)).

\footnotetext{
${ }^{4}$ Source: The London Docklands Development Corporation (http://www.lddc-history.org.uk/ beforelddc/index.html).

${ }^{5}$ Hall (2009) notes that "Before containerisation, ports in the developed world were all closely related to a clearly identifiable port-city and hinterland. The huge efficiencies afforded by containers loosened these highly local economic ties ..."

${ }^{6}$ Note that this collapse was not principally caused by a technological development, but rather a combination of political and longer-run economic factors.

${ }^{7}$ In a similar vein, Hinde (1994) studies displaced workers from another industry, shipbuilding, which experienced catastrophic job loss.

${ }^{8}$ But note that both Black et al. (2002) and Black et al. (2005) are concerned with the effect of exogenous shocks on the aggregate local labour market; whereas our focus is on the adjustment cost faced by incumbent workers.
}

${ }^{9} \mathrm{In}$ some ports there actually appears to have been a shortage of dock workers after deregulation. 
${ }^{10}$ Break-bulk shipping refers to the traditional method of transporting goods loose or in much smaller containers such as boxes, barrels or pallets.

${ }^{11}$ This partly reflected a compensating differential: dock-work was difficult and dangerous, with a high accident rate (Vigarié, 1999).

${ }^{12}$ Naturally, some workers did not like the loss of liberty and saw the new scheme as a form of labor control. In London, the dockers preferred irregular employment with the possibility of earning high wages when work was available. Hence strikes continued post 1947.

${ }^{13}$ Previously many dock-workers were hired on a daily basis from the pool of registered workers.

${ }^{14}$ Source: Port of London Authority.

${ }^{15}$ Table A1 shows that these major ports accounted for $95 \%$ of foreign sea tonnage in 1967. Information from ports.org.uk suggests that there were an additional 80 minor commercial ports in existence.

${ }^{16}$ The organisation of local government in England and Wales changed significantly in 1974 following the Local Government Act 1972.

${ }^{17}$ It is difficult to construct a consistent series of local authorities over the period 1961-2011, due to various local government re-organisations and classification changes. In addition, district-level population and employment estimates from published census tables in 1961 do not cover all districts. We therefore constructed a concordance from the 1971 local authority classifications to each of the other decades which inevitably means that some districts could not be cleanly defined as "port" or "non-port". The concordance is available on request from the authors.

${ }^{18}$ The DiD methodology does control for any differences which are fixed over time at the district-level.

${ }^{19}$ This information on the LS is taken from http://celsius.lshtm.ac.uk/what.html.

${ }^{20}$ These are the sea transport and port and inland water transport industries.

${ }^{21}$ ONS estimates from survey data that total employment in Spring 1971 was $24.5 \mathrm{~m}$, suggesting that our sample is slightly less than $1 \%$ (Lindsay and Doyle, 2003).

${ }^{22}$ Unfortunately the census educational classification from 1971 does not distinguish between any educational qualifications below A-level, which covers the great majority of the sample.

${ }^{23}$ OLS estimates are available in El-Sahli and Upward (2015).

${ }^{24}$ Note that if an individual attrits without a recorded year of death then mortality is missing, so the mortality outcome is conditional on appearance in the LS up until the previous census.

${ }^{25}$ One can compare the $D 3$ sample results to the district-level results shown in Section 3 . Table 1 shows that employment rates were between 4pp and 5pp lower in port districts between 1991 and 2011. Our estimates from the individual-level results are smaller (1.3pp in 1991 and 2.9pp in 2001).

${ }^{26}$ Counties are more aggregated geographical areas than districts. In 1971 there were 55 Counties in England and Wales, while there were 1,366 Local Authority Districts.

${ }^{27}$ Distances are computed between the midpoint of each Local Authority using geodetic distances (Picard, 2010).

${ }^{28}$ There was an occupational re-classification between 1971 and 1981.

${ }^{29}$ There is no wage information in the LS. 


\section{References}

Autor, D., Dorn, D., Hanson, G. and Song, J. (2014), "Trade adjustment: worker-level evidence", Quarterly Journal of Economics 129(4), 1799-1860.

Bernhofen, D. M., El-Sahli, Z. and Kneller, R. (2016), "Estimating the effects of the container revolution on world trade", Journal of International Economics -.

Black, D., Daniel, K. and Sanders, S. (2002), "The impact of economic conditions on participation in disability programs: Evidence from the coal boom and bust", American Economic Review 92(1), 27-50.

Black, D., McKinnish, T. and Sanders, S. (2005), "The economic impact of the coal boom and bust", The Economic Journal 115(503), 449-476.

Black, S., Devereux, P. and Salvjanes, K. (2012), "The effect of job displacement on health", NBER working paper 18660.

Bound, J. and Holzer, H. J. (2000), "Demand shifts, population adjustments, and labor market outcomes during the 1980s", Journal of Labor Economics 18(1), 20-54.

Cameron, C. and Trivedi, P. (2005), Microeconometrics: methods and applications, Cambridge: Cambridge University Press.

Central Statistical Office (1970), "Standard industrial classification". London: Her Majesty's Stationary Office.

Couch, K. A. and Placzek, D. W. (2010), "Earnings losses of displaced workers revisited", The American Economic Review 100(1), 572-589.

Davis, S. J. and von Wachter, T. (2011), "Recessions and the costs of job loss", Brookings Papers on Economic Activity Fall, 1-55.

El-Sahli, Z. (2012), "Estimating the effects of containerisation on world trade", PhD thesis, School of Economics, University of Nottingham.

El-Sahli, Z. and Upward, R. (2015), "Off the waterfront: the long-run impact of technological change on dock workers", GEP working paper 2015/06.

Eliason, M. (2012), "Lost jobs, broken marriages", Journal of Population Economics 25, 1365-1397.

Eliason, M. and Storrie, D. (2009), "Does job loss shorten life?", Journal of Human Resources 44(2), 277-302.

Fieldhouse, E. and Hollywood, E. (1999), "Life after mining: Hidden unemployment and changing patterns of economic activity amongst miners in England and Wales, 1981-1991", Work, Employment \& Society 13(3), 483-502. 
Hall, P. (2009), "Container ports, local benefits and transportation worker earnings", GeoJournal 74(1), 67-83.

Hattersley, L. and Creeser, R. (1995), "Longitudinal study 1971-1991: history, organisation and quality of the data", OPCS working paper LS 7.

Hinde, K. (1994), "Labour market experiences following plant closure: the case of Sunderland's shipyard workers", Regional Studies 28(7), 713-724.

Hoare, A. G. (1986), "British ports and their export hinterlands: A rapidly changing geography", Geografiska Annaler. Series B, Human Geography 68(1), pp. 29-40.

Jacobson, L. S., LaLonde, R. J. and Sullivan, D. G. (1993), "Earnings losses of displaced workers", The American Economic Review 83(4), 685-709.

Levinson, M. (2006), The Box: How the Shipping Container Made the World Smaller and the World Economy Bigger, Princeton University Press.

Lindsay, C. and Doyle, P. (2003), "Experimental consistent time series of historical labour force survey data", Labour Market Trends 467-475.

McVicar, D. (2008), "Why have UK disability benefit rolls grown so much?", Journal of Economic Surveys 22(1), 114-139.

Nickell, S. and Bell, B. (1995), "The collapse in demand for the unskilled and unemployment across the OECD", Oxford Review of Economic Policy 11, 40-62.

Office for Population Censuses and Surveys (1970), "Classification of occupations 1970". London: Her Majesty's Stationary Office.

Picard, R. (2010), "GEODIST: Stata module to compute geodetic distances", Statistical Software Components, Boston College Department of Economics.

URL: http://ideas.repec.org/c/boc/bocode/s457147.html

Rosenbaum, P. and Rubin, D. (1983), "The central role of the propensity score in observational studies for causal effects", Biometrika 70(1), 41-55.

Ruhm, C. (1991), "Are workers permanently scarred by job displacements?", American Economic Review 81, 319-324.

Talley, W. (2002), "Dockworker earnings, containerisation, and shipping deregulation", Journal of Transport Economics and Policy 36(3), 447-467.

Turnbull, P. (1992), "Dock strikes and the demise of the dockers' occupational culture", Sociological Review 40(2), $294-318$.

Turnbull, P. (2012), "Port labor", in W. K. Talley, ed., The Blackwell Companion to Maritime Economics, Wiley-Blackwell, chapter 26, 517-548. 
Turnbull, P., Morris, J. and Sapsford, D. (1996), "Persistent militants and quiescent comrades: intra-industry strike activity on the docks, 1947-89.", Sociological Review 44(4), $692-727$.

Turnbull, P. and Wass, V. (1994), "The greatest game no more - redundant dockers and the demise of dock work", Work, Employment $\&$ Society 8(4), 487-506.

Upward, R. and Wright, P. (2015), "Don't look down: New evidence from job loss in a flexible labour market", GEP working paper 15/14.

Vigarié, A. (1999), "From break-bulk to containers: the transformation of general cargo handling and trade", GeoJournal 48(1), 3-7. 


\section{Appendix A Port locations}

\begin{tabular}{|c|c|c|c|}
\hline Major Port & $\begin{array}{r}\text { Foreign } \\
\text { Tonnage } \\
(000 \mathrm{~s})\end{array}$ & $\begin{array}{r}\text { Est. port } \\
\text { employment }\end{array}$ & $\begin{array}{r}\text { Est. no. } \\
\text { stevedores }\end{array}$ \\
\hline London (inc. Tilbury) & 35,150 & 38,600 & 13,280 \\
\hline Liverpool & 22,687 & 29,330 & 13,470 \\
\hline Medway and Dover & 21,747 & 2,940 & 1,180 \\
\hline Milford Haven & 19,807 & 440 & 190 \\
\hline Southampton & 17,092 & 4,420 & 2,260 \\
\hline Manchester & 10,898 & 4,900 & 1,830 \\
\hline Tees and Hartlepool & 9,080 & 2,240 & 1,060 \\
\hline Hull & 5,519 & 8,780 & 4,520 \\
\hline Immingham & 5,472 & 3,290 & 1,820 \\
\hline Bristol & 4,248 & 4,410 & 1,750 \\
\hline Newport & 3,865 & 1,300 & 680 \\
\hline Port Talbot & 3,360 & 410 & 230 \\
\hline Swansea & 2,936 & 2,000 & 730 \\
\hline Tyne & 2,551 & 2,060 & 850 \\
\hline Cardiff & 1,940 & 1,870 & 580 \\
\hline Par and Fowey & 1,524 & 1,190 & 200 \\
\hline Felixstowe & 1,118 & 400 & 130 \\
\hline Goole & 837 & 1,600 & 410 \\
\hline Harwich & 817 & 780 & 410 \\
\hline Grimsby & 792 & 2,550 & 1,300 \\
\hline Preston & 762 & 840 & 320 \\
\hline Whitehaven and Workington & 757 & 310 & 160 \\
\hline Great Yarmouth & 691 & 370 & 120 \\
\hline Ipswich & 635 & 240 & 60 \\
\hline Boston & 539 & 310 & 220 \\
\hline Plymouth & 519 & 900 & 180 \\
\hline Shoreham & 470 & 180 & 30 \\
\hline King's Lynn & 449 & 310 & 220 \\
\hline Teignmouth & 326 & 130 & 60 \\
\hline Holyhead & 262 & 160 & 10 \\
\hline Barrow & 172 & 250 & 50 \\
\hline All major ports above & 177,022 & 117,510 & 48,310 \\
\hline All ports England and Wales & 185,904 & 132,750 & 59,190 \\
\hline
\end{tabular}

Table A1. Major English and Welsh ports by tonnage, 1967 and employment, 1961. Major ports are those listed individually in the Digest of Port Statistics, 1968. Employment is estimated from $10 \%$ published census tables, based on recorded employment in the Local Government Districts which contained a major port. 


\begin{tabular}{|c|c|c|}
\hline Major Port & Local authorities (1961) & Local authorities (1971) \\
\hline London (inc. Tilbury) & $\begin{array}{l}\text { City of London, Poplar, Stepney, } \\
\text { West Ham, East Ham, Barking, } \\
\text { Bexley, Dagenham, Hornchurch, } \\
\text { Southwark, Bermondsey, Deptford, } \\
\text { Greenwich, Woolwich, Erith, } \\
\text { Crayford, Thurrock }\end{array}$ & $\begin{array}{l}\text { Barking, Bexley, City of London, } \\
\text { Greenwich, Havering, Lewisham, } \\
\text { Newham, Southwark, Tower } \\
\text { Hamlets, Thurrock (Tilbury), } \\
\text { Gravesend (Tilbury), }\end{array}$ \\
\hline Liverpool & $\begin{array}{l}\text { Bootle, Crosby, Birkenhead, } \\
\text { Wallesey, Bebington, Liverpool }\end{array}$ & $\begin{array}{l}\text { Bebington, Birkenhead, Bootle, } \\
\text { Crosby, Ellesmere Port, Liverpool, } \\
\text { Runcorn, Wallasey }\end{array}$ \\
\hline Medway and Dover & $\begin{array}{l}\text { Gillingham, Kent (county } \\
\text { remainder) }\end{array}$ & $\begin{array}{l}\text { Gillingham, Chatham, Rochester, } \\
\text { Queenborough-in-Sheppey }\end{array}$ \\
\hline Milford Haven & Pembrokeshire & Milford Haven, Pembroke \\
\hline Southampton & Southampton & Southampton \\
\hline Manchester & Salford, Manchester, Stretford & Salford, Manchester, Stretford \\
\hline Tees and Hartlepool & Middlesbrough & Hartlepool, Teesside \\
\hline Hull & Kingston-upon-Hull & Kingston-up-Hull \\
\hline Immingham & Lincolnshire (parts of Lindsey) & Grimsby \\
\hline Bristol & Bristol & Bristol \\
\hline Newport & Newport & Newport \\
\hline Port Talbot & Port Talbot & Port Talbot \\
\hline Swansea & Swansea & Swansea \\
\hline Tyne & Tynemouth & South Shields, Tynemouth \\
\hline Cardiff & Cardiff & Cardiff \\
\hline Par and Fowey & Cornwall and the Isles of Scilly & St Austell with Fowey \\
\hline Felixstowe & Suffolk & Felixstowe \\
\hline Dover & Kent (county remainder) & Dover \\
\hline Goole & $\begin{array}{l}\text { Yorkshire West Riding (county } \\
\text { remainder) }\end{array}$ & Goole \\
\hline Harwich & Essex (county remainder) & Harwich, Tendring \\
\hline Grimsby & Grimsby & Grimsby \\
\hline Preston & Preston & Preston \\
\hline Workington & Cumberland & Workington \\
\hline Whitehaven & Cumberland & Whitehaven \\
\hline Great Yarmouth & Great Yarmouth & Great Yarmouth \\
\hline Ipswich & Ipswich & Ipswich \\
\hline Boston & Lincolnshire (parts of Holland) & Boston \\
\hline Plymouth & Plymouth & Plymouth \\
\hline Shoreham & Sussex (county remainder) & Shoreham-by-Sea, Southwick \\
\hline King's Lynn & Norfolk & King's Lynn \\
\hline Teignmouth & Devon (county remainder) & Teignmouth \\
\hline Holyhead & Anglesey & Holyhead \\
\hline Barrow & Barrow-in-Furness & Barrow-in-Furness \\
\hline
\end{tabular}

Table A2. Local authority areas classified as containing a major port in 1961 and 1971. 


\section{Appendix B Definition of labour market states}

\begin{tabular}{|c|c|c|c|c|}
\hline & 1981 & 1991 & 2001 & 2011 \\
\hline Employed & $\begin{array}{l}\text { In a full- or } \\
\text { part-time job at } \\
\text { any time in the } \\
\text { last week }\end{array}$ & $\begin{array}{l}\text { Employed or } \\
\text { self-employed in } \\
\text { the last week }\end{array}$ & Same as 1991 & Same as 2001 \\
\hline Unemployed & $\begin{array}{l}\text { Waiting to take } \\
\text { up job or seeking } \\
\text { job }\end{array}$ & $\begin{array}{l}\text { Waiting to start } \\
\text { job or seeking job }\end{array}$ & $\begin{array}{l}\text { Not working, } \\
\text { actively looking } \\
\text { for paid work in } \\
\text { last four weeks } \\
\text { and available to } \\
\text { start within two } \\
\text { weeks; or waiting } \\
\text { to start job }\end{array}$ & Same as 2001 \\
\hline Retired & $\begin{array}{l}\text { Wholly retired } \\
\text { from employment }\end{array}$ & $\begin{array}{l}\text { Retired from } \\
\text { paid work }\end{array}$ & Retired & $\begin{array}{l}\text { Retired (whether } \\
\text { receiving pension } \\
\text { or not) }\end{array}$ \\
\hline Sick & $\begin{array}{l}\text { Permanently sick } \\
\text { or disabled }\end{array}$ & $\begin{array}{l}\text { Unable to work } \\
\text { because of long } \\
\text { term sickness or } \\
\text { disability }\end{array}$ & $\begin{array}{l}\text { Permanently } \\
\text { sick/disabled }\end{array}$ & $\begin{array}{l}\text { Long-term sick or } \\
\text { disabled }\end{array}$ \\
\hline
\end{tabular}

Table B1. Definition of labour market states 1981-2011. 